\title{
Architektura wiejska w granicach Prus Zachodnich jako przedmiot zainteresowań naukowych i konserwatorskich do lat 40. XX w.*
}

\section{Wstęp}

$\Lambda_{\text {cowana. Charakterystyczne sa okazałe domy żuławskie, długie za- }}^{\text {rchitektura wiejska na terenie północnej Polski jest bardzo zróżni }}$ grody zespolone nizin nadwiślańskich czy podcieniowa zabudowa Kaszub. W okresie powojennym poświęcono im wiele prac naukowych, których część podejmuje również problematykę konserwatorską. Samo zaintereso-

\footnotetext{
Artykuł powstał w ramach grantu Narodowego Centrum Nauki nr DEC-2011/03/D/ HS3/03631.

1 Do opracowań ogólnych ujmujących zabudowę Pomorza należy zaliczyć: I. Tłoczek, Chatupy polskie, Warszawa 1958; A. Dobrowolska, Z problematyki budownictwa ludowego Warmii, Mazur i Powiśla w swietle badań niemieckich, „Rocznik Olsztyński”, t. 3, 1960, s. 189-216; M. Pokropek, Budownictwo ludowe w Polsce, Warszawa 1976; I. Tłoczek, Polskie budownictwo drewniane, Warszawa 1980; idem, Dom mieszkalny na polskiej wsi, Warszawa 1985; M. Pokropek, W. Pokropek, Tradycyjne budownictwo dræewne w Polsce, t. 1, Warszawa 1995; R. Tubaja, Muzea etnograficzne typu skansenowskiego na Pomorzu. Koncepcje i realizacja, „Biuletyn Stowarzyszenia Muzeów na Wolnym Powietrzu w Polsce” 2002, nr 5, s. 19-29. Dla ziemi chełmińskiej: K. Krajewski, Tradycyjne budownictwo chałup ziemi chełmińskiej, mps pracy doktorskiej, Torun 1965, w zbiorach Muzeum Etnograficznego w Toruniu; J. Święch, R. Tubaja, Budownictwo, [w:] Kultura ludowa ziemi chetmińskiej, Toruń 1978, s. 20-32. Dla Żuław i Dolnej Wisły: J. Stankiewicz, Zabytki budownictwa i architektury na Żuławach, „Rocznik Gdański”,
} 
wanie zabytkoznawcze tym zagadnieniem jest jednak znacznie starsze, sięga bowiem początków XIX stulecia.

Historia ochrona zabytków na Pomorzu ma również bardzo długą tradycję, związaną od XIX w. z pruskimi konserwatorami. Prace przez nich podejmowane były jednak do tej pory utożsamiane głównie z architektura militarną i sakralną (z Malborkiem na czele). Jedynie w kilku publikacjach zauważono, że działania te w 1. połowie XX w. koncentrowały się również na architekturze wiejskiej².

t. 15, 16, 1956-1957, s. 511-542; idem, Piotr Loewen - budownicsy żulawski, „Ochrona Zabytków”, 1956, nr 1, s. 73-87; L. Krzyżanowski, Wpływ neoklasycyzmu na podcieniowe budownictwo Żuław Gdanskich. Budowniçy Piotr Loewen, „Kwartalnik Architektury i Urbanistyki”, t. 8, 1963, z. 1, s. 63-79; Vermittlung von Dokumentationsmethoden an Baudenkmalen, T. 2, Beiträge zur Ländlischen Siedlung an Unterer und Mittlerer Wiechsel (U.A. Laubenbäuser), Oldenburg 1997; M. Warchoł, Budownictwo olederskie nad środkowa i dolna Wista, „Przegląd Regionalny”, R. 2, 1996-1997, nr 1, s. 51-80; J. Domino, Domy podcieniowe w powiecie elblaskim, „Warmińsko-Mazurski Biuletyn Konserwatorski”, R. 1, 1999, s. 85-97; R. Öhsen, Historische Holz̨bauten in der ländlichen Siedlung an unterer und mittlerer Weichsel, [w:] Zabytkowe budowle drewniane $i$ stolarka architektoniczna wobec wspótczesnych zagrożeń, red. E. Okoń, Torun 2005, s. 57-73; J. Domino, Budownictwo i cmentarze mennonickie na Żuławach Wiślanych, [w:] Mennonici na Żuławach. Ocalone dziedzictwo, Gdańsk 2007, s. 59-82; M. Prarat, Gdzie oledray mieszkeali... Z badań nad drewnianymi zagrodami na Niz̨inie Sartowcko-Nowskiej, Torun 2009; idem, Architektura chtopska Doliny Dolnej Wisly w latach 1772-1945 i jej problematyka konserwatorska, Toruń 2012. Dla Krajny: J. Burszta, Budownictwo wiejskie w kluczu runowskim w pierwszej połowie XVII w., „Kwartalnik Historii Kultury Materialnej” 1954, z. 1-2, s. 104-139. Dla Kujaw: M. Fryczowa, Tradycyjne budownictwo ludowe na Kujawach, Toruń 1961; J. Święch, Chtopskie budownictwo zagrodowe Kujaw w XIX i pierwszej potowie XX wieku, Kraków 2012. Dla Kaszub: J. Knyba, Budownictwo ludowe na Kaszubach, Gdańsk 1987. Odnośnie do wiatraków: R. Zacharias, Von den Müblen im Kreise Marienburg, Westoreussen Jahrbuch, Bd. 18, 1968, s. 99-104; W. Długokęcki, J. Kuczyński, B. Pospieszna, Mtyny w Malborku i okolicy od XIII do XIX wieku, Malbork 2004; J. Święch, Tajemnicsy świat wiatrakón, Lódź 2005; K. Laskowska, Żuławskie wiatraki csyli historia wiatrem pisana, Elbląg 2008.

2 Tekst T. Sadkowskiego jedynie w kilku zdaniach odnosi się do samej zagrody we Wdzydzach Kiszewskich, natomiast praca K. Bernhard koncentruje się na samej inwentaryzacji zabytków. Biogram B. Schmida, choć w głównej mierze podkreśla zasługi na polu ochrony zabudowy wiejskiej, omawia je jedynie w sposób hasłowy. Por. T. Sadkowski, Zinstytucjonalizowana opieka nad budownictwem drewnianym na Pomorzu Gdanskim (do 1939 r.), „Biuletyn Stowarzyszenia Muzeów na Wolnym Powietrzu” 2002, nr 5, s. 29-39; K. Bernhard, Inwentaryzacja zabytków sztuki pomiedsy nauka i polityka: Prusy Zachodnie i Wolne Miasto Gdansk, „Biuletyn Historii Sztuki”, nr 3 (2010), s. 263-293; M. Prarat, Bernhard Schmid, [w:] Etnografowie i ludoznawcy polscy. Sylwetki, szkice biograficæne, t. 3, (w druku). Najwięcej informacji na ten temat odnaleźć można w niepublikowanej pracy R. Paszkowskiego, poświęconej dzia- 
Przedstawienie rozwoju badań naukowych oraz podejmowanych prac konserwatorskich nad zabudową wiejską jest głównym celem niniejszej pra$\mathrm{cy}^{3}$. Zakres czasowy rozciaga się od lat 20. XIX w. do lat 40. XX w., co związane jest z ukazującymi się wówczas publikacjami. Zakres terytorialny obejmuje granice administracyjne prowincji Prusy Zachodnie, w skład której, w różnych okresach, wchodziły historyczne tereny ziemi chełmińskiej i Pomorza Nadwiślańskiego ${ }^{4}$. Był to także obszar bardzo zróżnicowany etnograficznie. Obejmował on Kaszuby, Żuławy, Powiśle, Kociewie, Bory Tucholskie, Krajnę, ziemię chełmińską i lubawską.

Tekst ten jest oparty w głównej mierze na licznych publikacjach, inwentarzach zabytków, sprawozdaniach konserwatorskich oraz zachowanych szczątkowo materiałach archiwalnych, znajdujących się w Archiwum Państwowym w Elblagu z siedzibą w Malborku. Ze względu na wielkość zebranego materiału artykuł podzielony został na trzy główne części. Pierwsza, przyjmując układ stanu badań, dotyczy zainteresowania zabytkoznawczego zabudową wsi. Kolejne przybliżaja konkretne działania konserwator-

łalności konserwatorskiej Bernharda Schmida. Jego główną częścią jest katalog sporządzony na podstawie sprawozdań konserwatorskich. W niniejszym artykule wszelkie informacje dotyczące tych działań oparte zostały w pierwszej kolejności właśnie na opracowaniu R. Paszkowskiego. Zob. R. Paszkowski, Działalność konserwatora zabytków Prowincji Prusy Zachodnie Bernharda Schmida w latach 1903-1941 - katalog, Toruń 2012, mps w zbiorach Zakładu Konserwatorstwa UMK.

3 W tekście tym, z racji ograniczonych ram, zrezygnowano z prezentacji działań podejmowanych przy kościołach wiejskich, tak drewnianych, jak i murowanych. Stanowią one osobne, bardzo szerokie zagadnienie. Z racji dużego zainteresowania badaczy na początku XX w. młynarstwem ujęto tu prace poświęcone średniowiecznym młynom miejskim.

4 W granicach takich prowincja funkcjonowała do 1919 r. W wyniku traktatu wersalskiego od Prus Zachodnich odpadła na rzecz Polski większa część Pomorza Gdańskiego z ziemią chełmińska, Kociewiem i częścią Kaszub. Obszar Krajny wszedł w nowo powstała prowincję Marchia Graniczna Poznańsko-Zachodniopruska. Powiaty kwidzyński, sztumski, malborski, suski i elbląski zostały dołączone do prowincji Prus Wschodnich i funkcjonowały w ich ramach jako regencja Prusy Zachodnie. Gdańsk z okolicami został w 1920 r. ogłoszony wolnym miastem. W czasie okupacji hitlerowskiej powstał Okręg Rzeszy Gdańsk-Prusy Zachodnie. Zob. K. Bernhard, op. cit., s. 267.

5 Na temat podziałów etnograficznych zob.: Tajemnice codzienności. Kultura ludowa i jej pogranicze od Kujaw do Bałtyku (1850-1950), red. H. Czachowski, H. Łopatyńska, Toruń 2010, s. $12-15$. 
skie $^{6}$ nad zagrodami i osobno młynami. We wstępie warto jednak w kilku zdaniach przybliżyć historię rozwoju instytucjonalnej ochrony zabytków w Prusach Zachodnich oraz początki zainteresowania architekturą wiejską w ogóle.

Pierwsze próby ochrony zabytków na terenie państwa pruskiego podejmowano już od końca XVIII w7 w $^{7} 1843$ r. król oficjalnie powołał konserwatora zabytków, którym został Ferdynand von Quast ${ }^{8}$. Kolejne zmiany nastąiły już po zjednoczeniu państwa niemieckiego, kiedy to w $1891 \mathrm{r}$. doszło do decentralizacji struktury służb ochrony zabytków9. Pierwszym konserwatorem prowincji Prusy Zachodnie został powołany na to stanowisko w 1892 r. Johannes Heise ${ }^{10}$. Postanowieniem sejmu prowincjonalnego z 24 lutego 1892 r. powołano także Prowincjonalną Komisję do Badań i Ochrony Zabytków Provinzial-Kommission zur Erforschung und zum Schutze der Denkmäler ${ }^{11}$. Następcą Heisego został Bernhard Schmid ${ }^{12}$. Na czele Miejskiego Doradztwa Budowlanego i Ochrony Zabytków w Wolnym Mieście Gdańsku w 1926 r. stanął Erich Volmar ${ }^{13}$. Znaczna część prowincji przeszła też pod polskie panowanie jako województwo pomorskie ${ }^{14}$. Podczas okupacji niemieckiej w latach 1939-1945 w utworzonym Okręgu Rzeszy Gdańsk-Prusy Zachodnie urząd konserwatora sprawował dalej Schmid, a od roku 1941 do końca wojny - wspomniany już Erich Volmar ${ }^{15}$.

6 W części zabytkoznawczej omówiono też inwentarze zabytków, choć należy mieć świadomość, że były one istotnym elementem działań konserwatorskich.

7 M. Arszyński, Idea, pamiéć, troska. Rola zabytków w przestrzeni społecznej i formy džiałania na rzecz ich zachowania od starosiytności do potowy XX w., Malbork 2007, s. 138.

8 Ibidem, s. 141.

9 H. Lezius, Das Recht der Denkmalpflege in Preussen, Berlin 1908, s. 27.

10 M. Arszyński, Heise Johannes, [w:] Polski stownik biograficzny konserwatorów zabytków [dalej: PSBKZ], Poznań 2006, z. 2, s. 88-89.

11 J. Heise, Die Denkmalpflege, ihre Entwickelung und Imre Organisation und die wichtigsten für dieselbe erlassenen Gesetze und ministeriellen Verfüngen, Danzig 1896, s. 12; H. Lezius, op. cit., s. 29.

12 R. Paszkowski, op. cit., s. 17-44.

13 M. Arszyński, Volmar Erich, [w:] PSBKS, Poznań 2006, z. 2, s. 283.

14 K. Zimna-Kawecka, „Działalność konserwatorska na terenie województwa pomorskiego w latach 1920-1939”, praca doktorska napisana pod kierunkiem prof. M. Arszyńskiego, UMK Toruń 2011, mps w zbiorach Zakładu Konserwatorstwa UMK.

15 M. Arszyński, Volmar..., s. 283. 
Z ochroną zabytków w Prusach związane jest jeszcze jedna osoba - Conrad Steinbrecht, kierownik Zarządu Odbudowy Zamku w Malbor$\mathrm{ku}^{16}$. To właśnie z tym miejscem w pierwszej kolejności utożsamiana była głównie ochrona zabytków w Prusach. Podczas prowadzonych tam prac na przestrzeni całego XIX i 1. połowy XX w. (badania architektoniczne wspomagane wykopaliskami archeologicznymi i kwerendami źródłowymi) rozwijała się metoda badań i konserwacji mająca wpływ na podejście do zabytków nie tylko w samej prowincji.

W XIX w. w pierwszej kolejności, obok Malborka, ochroną konserwatorską objęte zostały zamki, później również fortyfikacje miast i ratusze. Nieliczne prace podejmowano wówczas przy świątyniach ${ }^{17}$. Do poszerzenia pola działania doszło dopiero za czasów Schmida. Ważna stała się ochrona kamienic mieszczańskich Gdańska, Elblaga i Malborka, świątyń miejskich (nie tylko z czasów gotyku) czy wiejskich kościołów wieńcowych i szkieletowych wraz z licznym wyposażeniem ${ }^{18}$.

Zabudowa wiejska również znalazła się w tym kręgu, aczkolwiek zainteresowanie kultura ludową w Europie można zaobserwować już dużo wcześniej: w XVI-wiecznej Hiszpanii czy XVII-wiecznej Szwecji ${ }^{19}$. Dopiero jednak na przełomie XVIII i XIX w. w pełni zaczęły się wykształcać badania ludoznawcze, będące podstawą późniejszej etnografii ${ }^{20}$. Wiązało się to z ogólnym rozwojem poczucia tożsamości narodowej i zainteresowania przeszłością. Duży wpływ wywarły zmiany społeczne wiązane z rewolucja przemysłowa, która przyczyniła się do szybkiego zaniku kultury tradycyjnej. Postawa romantyczna 1. połowy XIX w. łączyła zainteresowanie ludoznawcze głównie na poziomie pieśni i obyczajów. Dopiero później

16 Idem, Dwieście lat troski konserwatorskiej o zamek kryyżacki w Malborku, [w:] Praeterita Posteritati. Studia z. historii sztuki i kultury ofiarowane Maciejowi Kilarskiemu, red. M. Mierzwiński, Malbork 2001, s. 50.

17 B. Schmid, Die Denkmaltflege in Westpreußen 1804-1910, Danzig 1910, s. 7-39. Na temat prac podejmowanych w Pelplinie patrz: I. Brzostowska, Vier Gutachten zur Restaurierung der Domkirche zu Pelplin. Zur Organisation der Die Denkmalpflege in Westpreußen in der 2. Häfte des 19. Jabrbunderts, [w:] Kunsthistoriker und Denkmalpfleger des Ostens. Der Beitrage zur Entwicklung des Faches im 19. Und 20. Jahrbundert, Bonn 2007, s. 63-75.

18 R. Paszkowski, Driatalność..., s. 43.

19 M. Arszyński, Idea, pamiéć..., s. 50, 67.

20 A. Spiss, Muzea etnograficzne na wolnym powietrzu w Europie, Warszawa 1985, s. 10. 
dostrzeżono całokształt kultury materialnej ludu. Pozytywizm i racjonalizm doprowadził natomiast nie tylko do gromadzenia zbiorów, ale także do ich uspołecznienia, upowszechnienia i propagowania edukacji w tym zakre$\operatorname{sie}^{21}$. Na wszystkie powyższe czynniki nałożyły się jeszcze wystawy światowe. W 1873 r. w Wiedniu zaprezentowano duże działy etnograficzne wraz z domami chłopskimi ${ }^{22}$. W tym samym czasie powstały pierwsze opracowania naukowe poświęcone architekturze wiejskiej ${ }^{23}$. Na kanwie wszystkich tych zainteresowań zaczęto tworzyć muzea na wolnym powietrzu ${ }^{24}$. Pierwszą taką placówkę powołał w Sztokholmie Artur Hezalius w 1891 r. Muzeum to prezentuje do dziś zagrody przeniesione z różnych terenów Szwecji wraz z wyposażeniem. Poza samą Szwecją tego typu placówki pojawiły się w końcu XIX w. również w Norwegii, Finlandii, Danii oraz Holandii ${ }^{25}$. Na terenie Niemiec pierwsze duże muzeum założył w latach 1909-1913 w Królewcu Richard Dethlefsen, konserwator prowincji Prusy Wschodnie ${ }^{26}$.

W 2. połowie XIX w. rozwinął się także ruch, który wprowadził w obieg pojęcie „małej ojczyzny”, związanej z badaniami tzw. wiedzy o swojszczyźnie. W 1888 r. w Berlinie założono Muzeum Folkloru i Sztuki Ludowej Museum für Volkskunde und Volkskunst27. W 1904 r. powołano Stowarzyszenie Ochrony Swojszczyzny Bund Heimatschut: Jednym z jego głównych zadań była ochrona zabytków traktowanych jako część środowi-

21 Ibidem, s. 11.

22 J. Czajkowski, Mužea na wolnym powietrzu w Europie, Rzeszów-Sanok 1984, s. 16.

23 K. J. Schröer, Das Bauernhaus mit seiner Einrichtung und seine Geräte, Wien 1874; A. Meitzen, Das deutsche Haus in seinem volkstümlichen Formen, Berlin 1882; R. Henning, Das deutsche Haus in seinem historischen Entwicklung, Strasburg 1882. Nieco później ukazały się również: Das Bauernbaus in Niederosterreich Und Sein Ursprung, Wien, Seidel 1897; Das Bauernhaus in Österreich-Ungarn und in seinen Grenagebieten, Vienna 1906.

24 S. Rentzhog, Open Air Museums. The history and future of a visionary idea, Carlssons-Jamtli 2007, s. 4-32.

25 J. Czajkowski, op. cit., s. 21.

26 R. Dethlefsen, Führer durch das ostpreußische Heimatmuseum, Königsberg 1913; idem, Ein ostpreußisches Heimatmuseum im Königsberg, Die Denkmalpflege 13, 1911, s. 101-104; Historia Ostpreussisches Heimatmuseum w Królewcu 1909-1945, dzisiejszego Muzeum Budownictwa Ludowego Parku Etnograficznego w Olsatynku, Katalog wystawy, Olsztynek 2011.

27 Pierwsze Heimatmuseum Vaterländische und Altertümliche Museum założono już w $1820 \mathrm{r}$. w Bonn. Zob. A. Spiss, op. cit., s. 30. 
ska ${ }^{28}$. Podejście to miało również silną wymowę polityczną. Idea krajobrazu kulturowego regionów, a więc również zabudowy chłopskiej w przestrzeni wsi, miała służyć celom umacniania władzy państwowej ${ }^{29}$.

\section{Zainteresowanie zabytkoznawcze architekturą wiejską}

Jedną z pierwszych prac naukowych poświęconych zabudowie wiejskiej w Prusach była artykuł Wutzkego z 1829 r. ${ }^{30}$ Główne rozważania autora dotyczyły stosowanych technik budowalnych. Niedługo później o zagrodach pisał również August Haxhausen ${ }^{31}$. Skoncentrował się on na występujących w północno-zachodniej części prowincji domach z podcieniem: szczytowym i narożnym oraz przy ścianie wzdłużnej charakterystycznym dla terenów nadwiślańskich. Dostrzegł też odmienność budynków na nizinach związanych $z$ menonitami. Scharakteryzował układy przestrzenne z czarnymi kuchniami oraz różne konstrukcje ścian ${ }^{32}$. Kolejny badacz, Heinrich Hecker, powołując się na pracę Meitzena, wyróżnił cztery podstawowe typy domów: frankoński, fryzyjsko-saski, szwajcarski i nordycki. Właśnie z ostatnim utożsamił architekturę na tym terenie, co potwierdził licznymi opisami ${ }^{33}$. W 1888 r. Conrad Steinbrecht, charakteryzując architekturę państwa zakonu krzyżackiego w Prusach, zwrócił uwagę na architekturę drewnianą w Golubiu z XVIII w. ${ }^{34}$ Za nim Johannes Heise, w tomie

28 B. Szmygin, Ksqtattowanie koncepiji zabytku i doktryny konserwatorskiej w Polsce w XX wieku, Lublin 2000, s. 13; M. Arszyński, Idea..., s. 146.

${ }^{29}$ K. Berhard, op. cit., s. 276.

30 Wutzke, Bemerkungen über die ländlichen Gebäude, besonders in Prenßen, „Preußische Provinzial Blätter”, Königsberg 1829, Bd. 2, s. 17-37.

31 A. Haxhausen, Die ländische Verfassung in den Provinzen Ost- und Westpreussen, Königsberg 1839, s. 69-74.

32 Przywołał także zarządzenie z 1818 r. dla rejencji kwidzyńskiej o zakazie budowy ścian z pełnego drewna. Zob. ibidem, s. 73-74.

33 H. Hacker, Über westpreußische Wohnbäuser in nordischem Typus, Zeitschrift des historischen Vereins für Regierungs-Bezirk Marienwerder, 1882, H. 7, s. 27-40.

34 C. Steinbrecht, Preußen zur Zeit der Landmeister. Beiträge zum Baukunst des Deutschen Ritterordens, Berlin 1888, s. 40-41. 
inwentarza zabytków z 1891 r. poświęconym powiatowi brodnickiemu, ponownie dokonał ich opisu ${ }^{35}$. Zainteresowanie konserwatorów tymi budynkami wynikało głównie z występowania podcienia, charakterystycznego wg nich elementu czasów kolonizacji średniowiecznej.

Kolejne opracowanie, autorstwa Bernharda Schmida z 1904 r., poświęcone było już całej grupie architektury drewnianej ${ }^{36}$. Autor dowodził jej znaczenia na równi z budynkami murowanymi. Przytaczając źródła, opisał przykłady budynków drewnianych już od XIII w. ${ }^{37}$ Wyróżnił pięć głównych grup: dzwonnic i wież kościelnych, kościołów wieńcowych i szkieletowych, zabudowy drewnianej miast ${ }^{38}$ oraz architektury chłopskiej. Mniejsze zagrody z wieńcową częścią mieszkalną oraz oborą i stodoła pod jednym dachem powiązał z dziedzicznymi dzierżawcami, a duże wolno stojące domy podcieniowe, częściowo szkieletowe, z chłopami na prawie chełmińskim ${ }^{39}$. Zwrócił uwagę również na podcieniowe stodoły oraz młyny wietrzne i odwadniające ${ }^{40}$.

W 1906 r. ukazały się jego kolejne cztery artykuły. W pierwszym, podczas pobytu w Toruniu, opisał na jednym przykładzie zabudowę chłopską niziny toruńskiej ${ }^{41}$. Dostrzegając wielką wartość tych zagród oraz ich szyb-

35 Die Bau- und Kunstdenkmäler des Kreises Strasburg, bearb. J. Heise, Danzig 1891, s. 345-247. Zob. również K. Bernhard, op. cit., s. 271.

36 B. Schmid, Westpreußische Holzbauten, Mitteilungen des Westpreußischen GeschichtsVereins, Jg. 3, 1904, s. 22-27.

37 Zastrzegł również, że nie należy upatrywać w konstrukcji wieńcowej lub szkieletowej cech narodowych. We wstępie wyjaśnił, że wieniec związany jest prawdopodobnie z wzorcami słowiańskimi lub pruskimi. Szkielet natomiast pojawił się wraz z kolonizacją niemiecka. Przytacza również XVII-wieczny opis, w którym fachwerk określany jest niemiecka robota. W XIX w. popularne były obie konstrukcje, stąd ich powiązanie narodowościowe byłoby błędne. Zob. ibidem, s. 22-24.

$38 \mathrm{~W}$ opisie wymienił ponownie domy w Golubiu. Zob. ibidem, s. 26.

39 Co ciekawe, Schmid określił również pochodzenie samej formy szkieletu, upatrując wzorców frankońskich i turyńskich. Zob. ibidem, s. 27.

40 Ibidem.

41 Poza niziną wyróżnił w prowincji zagrody kaszubskie, tucholskie oraz żuławskie. Większe rozeznanie typów zagród pozwoliło mu zauważyć, analizując rzut zagrody zespolonej z Nieszawki, że analogiczne układy występuja na całym terenie związanym z zakonem. Wymienia tu między innymi w Pr. Holland, Suszu i Oberlandzie, zaznaczając jednak, że nie ma starszych przykładów sprzed XVIII w. Porównując zaś z budownictwem zachodnim - wskazał na podobieństwa, w nieco zmienionej formie, z zabudową frankijską 
ki stopień destrukcji, przywołał muzea w Sztokholmie, Kopenhadze czy Husum, wyrażając nadzieję na powołanie takiej placówki pod Toruniem.

Kolejny tekst związany był z fundamentalnym opracowaniem poświęconym architekturze chłopskiej w Niemczech - Das Bauernhaus im Deutschen Reiche und in seinen Grenagebieten ${ }^{42}$. W rozdziale omawiającym zabudowę wiejską Prus Zachodnich, po wstępie o historii osadnictwa, Schmid scharakteryzował występujące układy przestrzenno-funkcjonalne. Omówił konstrukcję ścian, podług, kominów, a także stosowaną kolorystykę. Dostrzegał różnice wynikające z zamożności oraz statusu chłopów. Omówił zabudowę z Kaszub, Borów Tucholskich, niziny toruńskiej oraz Żuław. Jako zupełnie osobnym zjawiskiem zajął się podcieniem, dowodząc jego proweniencji z zabudowy miast na prawie niemieckim ${ }^{43}$. Na końcu osobno scharakteryzowal zagrody rybackie na Helu ${ }^{44}$.

W tym samym roku ukazał się pierwszy opracowany przez Schmida inwentarz zabytków powiatu suskiego. Już w jego wstępie Komisja Prowincjonalna ogłosiła, że będzie on obejmować jak najszerszy krag zabytków, włącznie z naczyniami, nagrobkami czy chatami wiejskimi. Dopiero bowiem tak szeroki przekrój dać może ogólny obraz historyczno-kulturalnego rozwoju regionu ${ }^{45}$. W opisie alfabetycznym zagrody nie zostały jednak omówione wraz z innymi zabytkami. Jedynie w zakończeniu konserwator zawarł ich kilkustronicowy zarys, upatrując w zachowanych domach wiejskich późnej formy budynków z czasów zakonu krzyżackiego ${ }^{46}$. Powo-

lub górnoniemiecka. Zob. Über ältere Bauernhäuser in der Thorner Niederung, Mitteilungen des Coppernicus-Vereins, 14, 1906, s. 51-53.

${ }^{42}$ Das Bauernhaus im Deutschen Reiche und in seinen Grenzgebieten, Dresden 1905-1906 (reprint Augsburg 2000).

43 Główną uwagę skupił na Żuławach, na Kaszubach zidentyfikował podcienie narożne (co przypisywał gorszym warunkom gospodarczym) Zob. B. Schmid, Provinz Westpreußen [w:] Das Bauernhaus im Deutschen Reiche und in seinen Grenagebieten, Dresden 1905-1906 (reprint Augsburg 2000), s. 223.

44 Ibidem, s. 221-224. Był on również autorem tekstu poświęconego zabudowie Pomorza Zachodniego. Zob. idem, Provinz Pommern, [w:] Das Bauernhaus im Deutschen Reiche und in seinen Grenzgebieten, Dresden 1905-1906 (reprint Augsburg 2000), s. 200-206.

45 Idem, Die Bau und Kunstdenkmäler des Kreises Rosenberg, Daznig 1906 (Die Bau und Kunstdenkmäler der Provinz, Wespreussen, H. XII), przedmowa do inwentarza. Zob. również: K. Bernhard, op. cit., s. 272-273.

46 B. Schmid, Die Bau und Kunstdenkmäler des Kreises Rosenberg, s. 230. 
łując się na pracę Henninga, Schmid wysnuł przypuszczenie o wpływie osadników frankońskich na ten typ zabudowy.

W 1909 r. wydano tom inwentarza zabytków dla powiatu sztumskiego. Część wstępu również poświęcona została charakterystyce zagród. Schmid zauważył duże zróżnicowanie narodowościowe tych terenów, gdzie spotkać można było język środkowoniemiecki, dolnoniemiecki i polski. Generalny układ zagród, wzorując się na wcześniejszym inwentarzu, wywiódł z typu górnoniemieckiego, natomiast domy z podcieniem szczytowym, charakterystyczne dla Prus Zachodnich, określił jako jego modyfikację. Zagrody zespolone formalnie powiązał z wpływami fryzyjskimi, zauważając jednak typowy dla całej prowincji układ funkcjonalny części mieszkalnej ${ }^{47}$. Rozwijając poprzedni tom, w opisie poszczególnych miejscowości znalazła się już charakterystyka wybranych budynków ze zdjęciami i rysunkami rzutów, m.in. w Starym Targu, Jasnej, Łozie, Ryjewie, Mątowskich Pastwiskach ${ }^{48}$. Osobno przedstawiona została historia młynówki Müblengraben wraz z opisem funkcjonujących tam młynów ${ }^{49}$.

Kilka zdań na temat zabudowy wiejskiej znalazło się w książce poświęconej ochronie zabytków w Prusach Zachodnich z 1910 r. Prace przy domach podcieniowych we Wdzydzach i Stalewie, które będa dokładnie omówione w kolejnej części tekstu, potraktowano łącznie z kamienicami mieszczańskimi jako przykład pomocy prywatnym właścicielom. Jak podkreślał Schmid, prawo pruskie było tu ograniczone i bez dobrej woli samych zainteresowanych nie można było podjąć żadnych kroków ${ }^{50}$.

W wydawnictwie Kaszubskiego Towarzystwa Ludoznawczego Mitteilungen des Vereins für Kaschubische Volkskeunde również ukazało się kilka tekstów o zabudowie wiejskiej. W jednym z nich B. Schmid ponownie podejmował problem proweniencji domów, łącząc je z kolonizacją krzyżacką ${ }^{51}$. I. Gul-

\footnotetext{
47 Die Bau-und Kunstdenkmäler des Kreises Stubm, Danzig 1909 (Die Bau- und Kunstdenkmäler der Provinz. Westpreußen, H. 13), s. 244.

48 Die Bau-und Kunstdenkmäler des Kreises Stubm..., s. 249-250, 289-292, 324-328.

49 Ibidem, s. 293-301.

50 B. Schmid, Die Denkmalpflege in Westpreußen 1804-1910 (Abhandlungen zur Landeskunde der Provinz. Westpreußen, H. 14), Danzig 1910, s. 28.

51 Aspekt ten rozważał w kontekście braku rozbudowanych części inwentarskich, które były charakterystyczne dla całej znanej ówcześnie grupy domów górnoniemieckich. W ko-
} 
gowski podkreślał znaczenie badań nad budownictwem regionalnym, prezentując różne typy domów podcieniowych ${ }^{52}$. Co najważniejsze, stwierdził, że badania nad ich rozwojem muszą być poparte bezpośrednimi działaniami konserwatorskimi, zmierzającymi do ich zachowania. Rozróżnił trzy możliwości ochrony: tworzenie pojedynczych izb chłopskich w muzeach miejskich, zakładanie muzeów na wolnym powietrzu w miastach oraz adaptację domów na muzeum w pierwotnym krajobrazie ${ }^{53}$. Działania te w pierwszej kolejności miały dotyczyć Helu, Żuław i Kaszub. W drugim rzędzie zaś okolic Elblaga czy domów podcieniowych w Golubiu. Do ochrony budownictwa nadawały się także miasta: Toruń, Chełmno, Grudziądz, Malbork i Elbląg ${ }^{54}$.

O zabudowie Kaszub wypowiadał się również A. Majkowski. W przeciwieństwie do niemieckich badaczy, nie zajmował się on proweniencją zabudowy, skupiając się na analizie zachowanych w terenie przykładów ${ }^{55}$.

W tym samym czasie ukazały się także popularnonaukowe teksty w czasopiśmie „Der Wandere durch Ost und Westpreussen”. Pierwszy au-

lejnych tekstach czynnik ten zaważył na wprowadzeniu przez Schmida pojęcia domu zachodniopruskiego. Zob. B. Schmid, Über das kassubische Bauernhaus, Die Denkmalpflege, Bd. 9, 1907, s. 51; idem, Über ältere Holz̧bauten in der Kaschubei, Mitteilungen der Vereins für Kaschubische Volkskunde, Bd. 2, 1910, H. 6, s. 72-73. W tym samym zeszycie znalazł się również tekst o podcieniowym domu autorstwa T. Paschkego. Zob. T. Paschke, Das strelliner Laubenhaus, Mitteilungen der Vereins für Kaschubische Volkskunde, Bd. 2, 1910, H. 6, s. 76.

52 I. Gulgowski, Das Bauernhaus in der Kaschubei. I - Allgemeiner Überblick, Mitteilungen der Vereins für Kaschubische Volkskunde, Bd. 1, 1910, s. 64-65.

${ }^{53}$ Idem, Das Bauernhaus in der Kaschubei. II - Die Laubenbäuser, Mitteilungen der Vereins für Kaschubische Volkskunde, Bd. 1, 1910, s. 97-98. Dodatkowo w tym samym tomie zawarł tekst poświęcony chatom bez kominów. Idem, Das Bauernhaus in der Kaschubei. III Rauchbäuser, s. 194-202.

54 Zob. również: idem, Jak ludność wiejska mies₹ka na Kasæubach, „Gryf”, R. 5, 1921, nr 3, s. 85 .

55 A. Majkowski, Chaty podcieniowe w Skorzemie, Praycsynek do bistoryi budownictwa ludowego na Kaszubach, „Gryf”, R. 1, 1908, z. 1, s. 17-20; idem, Chaty podcieniowe w Skorzenie, Prayczynek do bistoryi budownictwa ludowego na Kaszubach - II, „Gryf”, R. 1, 1909, z. 7, s. 198-203; idem, Śparogi i pazdury u chat kaszubskich, „Gryf”, R. 1, 1909, z. 9, s. 271-276; A. Majkowski, Odmiana chaty mystawkowej w Gostomku, „Gryf”, R. 2, 1910, z. 6, s. 182-185. O zabudowie Kaszub pisał równiez B. Chrzanowski. Zob. B. Chrzanowski, Do sprany chat podcienionych na Kaszubach, „Gryf”, R. 2, 1910, z. 2, s. 51-52; idem, Prayczynek do pazdurów na Kaszubach, „Gryf”, R. 2, 1910, z. 2, s. 53. 
torstwa H. Mankowskiego dotyczył ogólnej prezentacji zagród wschodnioniemieckich, wśród których znalazła się zabudowa Żuław Wiślanych, Kaszub i Borów Tucholskich ${ }^{56}$. Drugi - w formie przewodnika po Żuławach autorstwa Schmida, został napisany w nurcie badań nad swojszczyzną. Próbując przedstawić charakterystyczny krajobraz nizin, ważną w nim rolę przypisał m.in. wiatrakom ${ }^{57}$.

Nieco inny charakter miał tekst $\mathrm{H}$. Wernickego dotyczący zagród na terenie niziny kwidzyńskiej. Poza szczegółową prezentacją najciekawszych zabytków, autor szeroko omówił historię właścicieli zagród ${ }^{58}$.

Najstarszy zachowany dom drewniany na Pomorzu w Gdańsku-Lipcach przedstawiony został, łącznie z rysunkami, w doktoracie poświęconym kamienicom Gdańska z lat 1910-1915 autorstwa Otto Rollenhagena ${ }^{59}$.

W 1919 r. B. Schmid wydał publikację traktująca zabudowę chłopska w bodaj najszerszym zakresie. Mowa tu o inwentarzu powiatu malborskiego. Już we wstępie, za rozwojem osadnictwa, architektury sakralnej i wyposażenia, autor przedstawił szeroką charakterystykę zabudowy wiejskiej ${ }^{60}$. Zebrany materiał terenowy pozwolił mu na dokładniejszą systematykę zagród i podział wolno stojących domów podcieniowych na dwie grupy. Spostrzegł również zależność między używanym na danym terenie dialektem języka niemieckiego a formami domów tam występujących ${ }^{61}$. Omówił wyposażenie, a także budynki inwentarskie, wprowadzając ich klasyfikację. Szerzej scharakteryzował młyny, stanowiące ważną część kultury chłopskiej.

56 H. Mankowski, Alte deutsche Bauernbäuser, Der Wandere durch Ost und Westpreussen, Jg. 7, 1910, nr 5, s. 117-118.

57 B. Schmid, Wanderung durch das Marienburger Werder, Der Wandere durch Ost und Westpreussen, Jg. 8, 1911, nr 2, s. 28-31.

58 H. Wernicke, Bauernbäuser der Marienwerder Niederung und die Geschichte ibren Bewohner, „Zeitschrift des Historischen Vereins für Reg.-Bez. Marienwerder”, H. 50, 1912, s. 1-40.

59 O. Rollenhagen, Untersuchung und Beschreibung der Danziger Bürgerbäuser mit besonderer Darstellung der Bauten aus der Zeit der Gotik bis zur Spätrenaissance. Analiza i opis gdańskich kamienic mieszczańskich ze szcrególnym uwaglednieniem budowli z. czasów od gotyku do późnego renesansu, hrsg. E. Barylewska-Szymańska, E. Bauer, D. Popp, W. Szymański, Marburg-Gdańsk 2008, il. 20, 21, 93, 94.

${ }^{60}$ B. Schmid, Die Bau-und Kunstdenkmäler des Kreises Marienburg. 1. Die Städte Neuteich und Tiegenhof und die ländlichen Ortschaften, Danzig 1919, s. LXXIV-LXXXVIII.

${ }^{61} \mathrm{~W}$ wielu wypadkach ludność posługująca się plattdeutsch mieszkała w zabudowie o cechach górnoniemieckich. Zob. ibidem, s. LXXVI. 
Wśród wiatraków rozróżnił koźlaki i holendry oraz młyny końskie, służące albo do przemiału, albo do odwadniania nizin. Wśród źródeł archiwalnych odnalazł również informację o pływających na Nogacie młynach łodnych w XV w. ${ }^{62}$ Po raz pierwszy zespół ten został tak szczegółowo zaprezentowany w samym inwentarzu ${ }^{63}$. W głównej mierze opisał domy podcieniowe, powstałe przeważnie od 2. połowy XVIII do XIX w. Zamieszczone licznie zdjęcia były często uzupełniane rzutami przyziemia czy rysunkami elewacji lub detalu. Mając warsztat badacza architektury, Schmid dostrzegał również nawarstwienia i w kilku rysunkach rzutów próbował wprowadzić rozwarstwienie chronologiczne czy rekonstrukcję pierwotnego stanu.

W 1920 r. ukazał się obszerny tekst Steinbrechta poświęcony Wielkiemu Młynowi w Gdańsku (il. 1) ${ }^{64}$. Był on oczywiście wynikiem zainteresowania autora architektura państwa zakonu krzyżackiego. Materiał pomiarowy sporządzony został już w 1880 r., kiedy to działały pierwotne urządzenia, łącznie z 18 kołami młyńskimi. W bardzo szczegółowy sposób omówił cała jego przestrzeń, łącznie z historycznym procesem przemiału.

W tym czasie ukazała się również pierwsza monografia poświęcona zabudowie chłopskiej delty Wisły O. Kloeppela ${ }^{65}$. Zakrojone badania terenowe pozwoliły autorowi na rozszerzenie podziału zaproponowanego przez Schmida. Rozróżnił on dwa główne okresy kolonizacji. Pierwszemu, średniowiecznemu przypisał trzy typy domów wolno stojących z podcieniem: górnoniemiecko-frankoński, dolnoniemiecko-saski oraz typ mieszany ${ }^{66}$. Drugi okres od połowy XVI w. wiązał głównie z osadnikami holenderskimi,

62 Ibidem, s. LXXXVII.

${ }^{63}$ Opisy do zabytków architektury chłopskiej odnajdujemy dla wsi: Stare Pole, Stara Kościelnica, Kamienica, Jasionna, Fiszewo, Żuławki, Gnojewo, Stogi Malborskie, Klecie, Królewo Malborskie, Oleśno, Lubieszewo, Lasowice Wielkie, Marynowy, Nowa Cerkiew, Nowa Kościelnica, Orłowskie Pole, Złotowo, Różany, Ostaszewo, Krasnołęka, Stalewo, Świerki, Szalewiec, Tuja. Ibidem, s. 7, 33, 36, 48, 54, 66, 69, 79-80, 86-89, 116, 168, 204, 206-207, 251, 257-260, 280, 291-292, 304, 316-319, 331, 341-345.

${ }^{64}$ C. Steinbrecht, Die Baukunst des Deutschen Ritterordens in Preußen, Bd. 4: Die Ordensburgen der Hochmeisterzeit in Preußen, Berlin 1920, s. 6-10.

${ }^{65}$ Praca ta ukazała się w tym samym roku jako monografia i jej część poświęconej delcie Wisły. Zob. H. Bertram, W. La Baume, O. Kloeppel, Das Weichsel - Nogat - Delta, Danzig 1924, s. 107-216 oraz O. Kloeppel, Die bänerliche Haus-, Hof und Siedlungsanlage im WeichselNogat-Delta, Danzig 1924.

${ }^{66}$ Ibidem, s. 144-150. 
menonitami ${ }^{67}$. Z nimi to utożsamił zagrody zespolone, dokonując podziału ze względu na ustawienie części stodolnej. Każdy typ scharakteryzowany został kilkoma przykładami budynków, do których wykonano zdjęcia oraz rysunki rzutów, przekrojów i widoków ${ }^{68}$.

Jedyna monografia zabudowy chłopskiej z 1938 r. autorstwa Schmida dotyczyła terenów północnej Wielkopolski (powiatów człuchowskiego, wałeckiego i złotowskiego, wchodzących w pewnym okresie w skład prowincji zachodniopruskiej) ${ }^{69}$. Praca podzielona została na osiem głównych rozdziałów. W rozdziale historycznym przybliżono dzieje powiatów. Kolejny dotyczył układów wsi, podziałów pól i warunków geograficznych determinujących osadnictwo. Opisując formę domów, autor zwrócił uwagę na trzy zasadnicze wzorce kolonizacyjne - państwa zakonu krzyżackiego, Pomorza Przedniego oraz Nowej Marchii Brandenburskiej. Osobno scharakteryzował system paleniskowo-dymny, nadając mu podstawowe znaczenie w rozważaniach nad rozwojem zabudowy. Kolejna część dotyczyła podcienia, dalej zaś występowały informacje na temat konstrukcji wieńcowej, układu i inskrypcji, a także rozwoju domów w XIX w. Warto zaznaczyć, że badacz coraz ostrożniej podchodził do kwestii proweniencji domów, argumentujacc, że najstarsze zachowane budynki pochodzą z 1. połowy XVIII w. Stąd nie można było odnieść ich form do XIV czy XV w. ${ }^{70}$ We wszystkich elementach budynku dopatrywał się jednak bezpośrednich wzorców niemieckich.

W latach 30. XX w. na temat budownictwa wiejskiego Pomorza wypowiedział się również Gerard Ciołek, który w pierwszej monografii zagród w granicach II Rzeczpospolitej zaliczył interesująca nas zabudowę do grupy I niżowo północno-wschodniej ${ }^{71}$. Autor ten w sprawie domów podcieniowych jeszcze raz zabral głos w 1939 r., skupiając się głównie na zasadzie

\footnotetext{
67 Ibidem, s. 186.

${ }^{68}$ Jeszcze raz na ten temat wypowiedział się Schmid w 1926 r., powtarzając przyjęty wcześniej schemat na domy - wolno stojące (saskie i górnoniemieckie) oraz zespolone - holenderskie. Zob. B. Schmid, Marienburger Heimatbuch, Marienburg 1926, s. 326-331.

69 Idem, Das Bauernhaus der nördlichen Grenzmark, Schneidemühl 1938.

70 Ibidem, s. 14.

71 Omówił jednak tylko teren wchodzący w skład II RP. Zob. G. Ciołek, Regionaližm w budownictwie wiejskim, Kraków 1984, s. 104, 140-149.
} 
kompozycji fasady ${ }^{72}$. W tym samym roku ukazała się praca Ericha Kulkego. Był to kolejny badacz opowiadający się za jednoznacznie germańskim pochodzeniem podcienia, zakreślający szerokie granice jego występowania ${ }^{73}$.

Zainteresowanie kultura ludową w prowincji było również przyczyną powołania do życia w 1926 r. przez Waldemara Heyma Heimatmuseum w Kwidzynie. Dzięki jego działalności zebrany został bardzo duży zbiór wyposażenia domów nadwiślańskich. Wykonał on także szereg zdjęć dokumentujących życie wsi ${ }^{74}$.

Podsumowując tę część, należy stwierdzić, że naukowe badania nad domem chłopskim mają na terenie Pomorza długa tradycję. Stan XIX-wiecznej wiedzy pozwalał już na podstawowy podział typologiczny. Większość badaczy skupiała się na proweniencji, dowodząc wpływów niemieckich. $\mathrm{Z}$ dzisiejszej perspektywy prace te mają wielkie znaczenie, dzięki bardzo szczegółowo zawartym tam opisom budynków. Na początku XX w. dostrzegano już zróżnicowanie zagród żuławskich z terenów nadwiślańskich czy Kaszub i próbowano przedstawić ich bardziej szczegółową typologię. Już wtedy do najstarszych znanych zagród zaliczano te pochodzące z połowy XVIII w. Dostrzegano w nich takie cechy wspólne dla szerszego kręgu kulturowego, jak układ przestrzenno-funkcjonalny czy forma podcienia. Były jednak i rozwiązania typowo lokalne. Stąd też B. Schmid wprowadził do nauki pojęcie domu zachodniopruskiego. Zawsze wywodził jednak pochodzenie tej zabudowy z kolonizacji niemieckiej w średniowieczu. Wydane przez niego dwie prace monograficzne, stanowiące do dziś podstawowa literature przedmiotu, nie odbiegaja metoda od dzisiejszych publikacji (Schmid przy analizie zabudowy wykorzystywał na równi badania terenowe i archiwalne). Zawarty w nich bogaty materiał rysunkowy i foto-

72 G. Ciołek, Chałupy podcieniowe na Pomorzu, „Biuletyn Historii Sztuki i Kultury”, R. VII, 1939, nr 2, s. 169-176.

73 E. Kulke, Die Laube als ostgermanisches Baumerkmal unter besonderer Berücksichtigung der Bauernhöfe an der Unteren Oder, Hoheneichen 1939, mapa po s. 103.

74 W. Heym, Bericht über die Tätigkeit des Heimatmuseums „Westprenßen“ in Marienwerder für die Zeit vom 1. April 1925 bis 31. März 1926, Zeitschrift des historischen Vereins für Regierungs-Bezirk Marienwerder, H. 64, 1925, s. 53-64. Heym analizował również zagrody chłopskie, wykorzystując metodę badań archeologicznych. Zob. W. Heym, Beiträge zur Geschichte der Bauernhäuser rechts und links der unteren Weichsel, „Beiträge zur Geschichte Westpreußens”, Münster 1969, nr 2, s. 135-151. 
graficzny był głównie wynikiem szerokich badań terenowych, możliwych do przeprowadzenia w dużej części dzięki pracom nad inwentarzami zabytków.

Przedstawiona tu charakterystyka rozwoju zainteresowania naukowego zabudową wsi ma oczywiście bardzo ogólny charakter. Ich szczegółowa analiza, np. o rozwoju wiedzy na temat układu przestrzenno-funkcjonalnego czy paleniskowo-dymnego lub samego podcienia, wymaga oddzielnej, szczegółowej charakterystyki, niemieszczącej się w ramach tej pracy. W przyszłości wiedza ta powinna być również skonfrontowana na szerszym tle historii badań nad rozwojem domu w Europie ${ }^{75}$. Najważniejsze jednak jest to, że tak szerokie rozpoznanie zabudowy przyczyniło się do konkretnych działań konserwatorskich dla najcenniejszych przykładów architektury.

\section{Działania konserwatorskie podejmowane przy zagrodach}

Pierwsze prace konserwatorskie przy domu chłopskim odnotowane zostały w sprawozdaniu konserwatora prowincji w $1906 \mathrm{r}^{76}$ Opisana została tam podcieniowa chata z Wdzydz Kiszewskich Sanddorf, którą zakupił nauczyciel Izydor Gulgowski celem utworzenia w niej lokalnego muzeum (il. 2). Według Schmida poprzez swoją formę, konstrukcję oraz charakterystyczne położenie w krajobrazie należało wykonać przy niej prace remontowe przywracające oryginalny stan, łącznie z wyposażeniem. Środki na ten cel przeznaczyło ministerstwo oraz powiat kościerski. Jednocześnie konserwator zastrzegł, że nie przewiduje się przeniesienia owej chaty do stolicy prowincji, ponieważ jej pierwotna lokalizacja jest najbardziej właściwa ${ }^{77}$. Całościowy koszt zakupu, wymaganego remontu i wyposażenia wyliczono na 900 marek, z czego minister przyznał 400, zarząd prowincji 250 oraz powiat

75 K. Bedal, Historische Hausforschung, Münster 1978, s. 6-11.

76 Die Denkmalpflege in der Provinz. Westprenßen im Jahre 1906. Bericht an die Provinzialkommission zur Verwaltung der westpreußischen Provinzialmuseen zu Danzig erstattet vom Provinzialkonservator, Danzig 1907, s. 9-10; R. Paszkowski, op. cit., katalog nr 264.

77 Die Denkmalpflege in der Provinz. Westpreußen im Jabre 1906..., s. 10. 
kościerski $200^{78}$. W kolejnych latach zrekonstruowano typowy dla Kaszub piec ceramiczny i powiększano kolekcję wyposażenia. Gulgowski chciał pokazać wszystkie aspekty życia na Kaszubach, tj. rolnictwo, rybołówstwo, ubiór czy tkactwo. W 1909 r. zbiory powiększyły się m.in. o bogato malowany kredens, serię malowanych na szkle świętych, czepców i naczyń na święconą wodę. Zakupiono będące jeszcze w użytku trzy drewniane łodzie rybackie ${ }^{79}$. Ścisła współpraca i pomoc władz pruskich w utrzymaniu i gromadzeniu zbiorów muzeum przysporzyła jednak Gulgowskiemu również i krytyki, zwłaszcza przez czołowych działaczy kaszubskich. Tak o placówce w 1912 r. pisał Aleksander Majkowski, próbujący powołać w Sopocie Muzeum Kaszubskie: „Sprawa nagli, gdyż Niemcy w celach giermanizacyjnych już od sześciu lat posiadają muzeum kaszubskie we Wdzydzach popierane hojnie przez władze" $\$$.

$\mathrm{Na}$ terenie Żuław za początek działalności konserwatorskiej należy uznać przeprowadzenie remontu domu podcieniowego w Stalewie Stalle w lecie 1908 r. (il. 3). Już rok wcześniej w kwietniu do konserwatora zgłosił się właściciel zagrody z prośbą o dofinansowanie remontu. W złym stanie była konstrukcja szczytów, szczególnie po stronie zachodniej i południowej. Słupy podcienia były nadgnite. Konserwator określił dwie możliwości działania. Wymiany szczytów i ich odeskowanie lub przywrócenie ich pierwotnej formy, co było jednak znaczenie droższe. Właściciel wnioskował o dotację w wysokości 2450 marek. Schmid w sierpniu tego samego roku wystosowal pismo do konserwatora Prus Lutscha ${ }^{81}$. W odpowiedzi mini-

\footnotetext{
78 Postęp prac konserwatorskich zawarty został w sprawozdaniu za 1907 r. Zob. Die Denkmalpflege in der Provinz. Westpreußen im Jahre 1907. Bericht an die Provinzialkommission zur Verwaltung der westpreußischen Provinzialmuseen zu Dan₹ig erstattet vom Provinzialkonservator, Danzig 1908, s. 12 - Sanddorf (Kreis Berent). Einkauf eines älteren Bauerhauses. Zob. ibidem, s. 13.

79 Die Denkmalpflege in der Provinz. Westpreußen im Jahre 1909. Bericht an die Provinzialkommission zur Verwaltung der westpreußischen Provinzialmuseen zu Dan₹ig erstattet von Bernh. Schmid Provinzial-Konservator, Danzig 1910, s. 9 - Sanddorf (Kreis Berent). Bauernhaus-Museum. O zagrodzie zob: Ein Bauernmuseum in Kassubei, Der Wanderer durch Ost und Westpreußen, 1.10.1906, s. 189-190.

${ }^{80}$ Wiosna europejskich muzeón na wolnym powietrzu. Katalog wystany w stulecie muzealnej inicjatywy Teodory i Izydora Gulgowskich we Wdzydzach, Wdzydze Kiszewskie 2006, s. 13.

${ }^{81} \mathrm{~W}$ piśmie tym omówił dużą wartość domów żuławskich, wymieniając te najważniejsze z połowy XVIII w. w Kleciu, Oleśnie i Stalewie. Nadmienił, że ich zachowanie powinno
} 
sterstwo przyznało na ten cel 1100 marek $^{82}$, Wydział Powiatowy w Malbor$\mathrm{ku}-500^{83}$, a Komisja Prowincjonalna $-400^{84}$. Kierownikiem prac był sam Bernhard Schmid, wykonawca mistrz ciesielski Goldmann. Podczas prac przywrócono ciemną kolorystykę elementów konstrukcyjnych, które wcześniej były zamalowane razem $\mathrm{z}$ wypełnieniem. Strop głównej izby z widocznymi belkami miał malowane alegoryczne przedstawienie Czterech Pór Roku. Podczas prac przy podłodze piętra belki zostały odsłonięte i zabezpieczone. Chorąiewki - wiatrowskazy na szczytach, miały zachowane ślady kolorystyki czerwonej i częściowo złoconej. Ponieważ miedź była ładnie spatynowana, nie przywracano pierwotnego stanu. Ostateczny koszt prac wyniósł ponad 5000 marek $^{85}$. Opisując budynek w sprawozdaniu konserwatorskim, Schmid pokusił się również o wykonanie rysunku z rozwarstwieniem chronologicznym oraz rekonstrukcja pierwotnego stanu ${ }^{86}$.

W 1911 r. prace przeprowadzono przy kolejnym podcieniu domu Friedricha Hube z 1793 r. w Wilkowie Wolfsdorf-Höhe koło Elblaga (il. 4). Analogicznie do Stalewa, 26 maja 1910 r. wniosek o remont złożył sam właściciel. Także tu można było postapić dwojako. Likwidacja dotychczasowego szczytu i zastapienie go szczytem odeskowanym kosztować miała 130 marek, koszt naprawy zaś z uzupełnieniem zniszczonych elementów wyceniono na 750. Prowincja i powiat przyznały na ten cel po 260 marek. Konieczna była również naprawa dolnych części trzech filarów podcienia, wymiana ich podwaliny, a także zmurszałych elementów dekoracyjnych szczytu. Elementy szkieletu pomalowano na brunatno-czerwono, a otynkowane wypełnienie na jasno-żółto-zielony ${ }^{87}$.

leżeć w interesie państwa. Zob. Archiwum Państwowe w Elblagu z siedzibą w Malborku [dalej: APE], Wydział Powiatowy w Malborku, sygn. 103, k. 5-10.

82 Ibidem, k. 16.

83 Ibidem, k. 21.

84 Die Denkmalpflege in der Provinz. Westpreußen im Jahre 1908. Bericht an die Provinzialkommission zur Verwaltung der westpreußischen Provinzialmuseen zu Danzig erstattet vom Provinzialkonservator, Danzig 1909, s. 14; R. Paszkowski, op. cit., katalog nr 216.

${ }^{85}$ Rachunek za prace został ostatecznie zatwierdzony w listopadzie 1908 r. Zob. APE, Wydział Powiatowy w Malborku, sygn. 103, k. 31-37.

${ }_{86}$ Die Denkmalpflege in der Provinz Westpreußen im Jabre 1908..., s. 13-14, Abb. 9, 10.

${ }^{87}$ Die Denkmalpflege in der Provinz. Westpreußen im Jahre 1911. 9 Bericht an die Provinzialkommission zur Verwaltung der westpreußischen Provinzialmuseen zu Danzig erstattet von Bernh. Schmid 
W tym samym roku podjęto prace przy domu podcieniowym w Golubiu Gollub. Dwa budynki, opisywane już przez Steinbrechta, zostały w latach 1910-1911 rozebrane. W krótkim wstępie do prac konserwatorskich Schmid przedstawił zasięg występowania podcienia na terenie Prus Zachodnich. W przypadku zabudowy miejskiej typ ten można było jeszcze spotkać poza Golubiem w Dzierzgoniu, Kwidzynie, Malborku i Gniewie. 6 maja 1909 r. właściciel zwrócił się do prezydenta rejencji z prośbą o dofinansowanie remontu. Przy ogólnym koszcie 900 marek, ministerstwo przyznało 300, prowincja 200, a powiat wąbrzeski 100. Prace w 1911 r. przeprowadził Powiatowy Urząd Budowlany w Wąbrzeźnie. Wzmocniono fundamenty i więźbę dachową oraz wymieniono pokrycie dachu ${ }^{88}$.

Obszerny tekst dotyczący ochrony zabudowy wiejskiej ukazał się w 17. sprawozdaniu konserwatora prowincjonalnego za lata 1920-1932 ${ }^{89}$. Schmid, omawiając w nim możliwości zachowania zagród, przedstawił właściwą dla siebie metodę. Z jednej strony praktykował zakup budynków przez stowarzyszenia samorządowe, co miało miejsce w prowincji Poznań-Prusy Zachodnie, gdzie nabyto dom z 1742 r. Można było także wykonać kopie jak w muzeum królewieckim. Inna metodą było zbieranie funduszy na prace remontowe, które jak pokaże praktyka, były przez konserwatora najbardziej cenione $^{90}$. Te miały głównie sprowadzać się do wzrostu ochrony przeciwpożarowej oraz zachowania podcieni. Po 1919 r., gdy przesunięciu uległy wcześniejsze granice prowincji, niezmiernie ważny stał się także cel, jaki architektura regionalna spełnić miała w obronie niemieckości na Wschodzie $^{91}$. Od tego też okresu widoczna jest wzmożona pomoc państwa przy zachowaniu zabudowy wiejskiej.

W 1928 r. przeprowadzono prace przy murowanym domu podcieniowym z przełomu XVIII i XIX w. we wsi Złotowo Reichfelde oraz podcie-

Provinzial-Konservator, Danzig 1912, s. 21; R. Paszkowski, katalog nr 251.

88 Die Denkmalpflege in der Provinz. Westpreußen im Jabre 1911..., s. 13.

89 Die Denkmalpflege in der Provinz. Westpreußen in den Jabren 1920 bis 1931. 17 Bericht an den Ausschluss zur Erforscbung und zum Schutze der Denkmäler in der Provinz Ostpreussen erstattet von Bernhard Schmid Provin₹ialkonservator für den Regierungsbęirk. Westpreussen, Königsberg 1932, s. 22-28.

90 Ibidem, s. 23.

91 Ibidem. 
niowym domu z trzema ozdobnymi szczytami z 1795 r. we wsi Oleśno Preußische Königsdorf ${ }^{92}$. W 1929 r. dofinansowano prace przy domu podcieniowym z 1750 r. w Kleciu Klettendorf oraz zagrodzie z 1802 r. w Olszanicy Ellerwalde ${ }^{93}$. Rok później wyremontowano zagrodę z podcieniem szkieletowym z Pastwy Gross Weide z 1762 r., przez której ogród przebiegała granica państwa. W 1931 r. dofinansowano prace przy zagrodzie podcieniowej w Kaniczkach Kanitzken z 1757 r. i Starym Polu Alterfeld z 1798 r. Dom w Wiślinach Weichselburg z 1802 r. zbudowany został dla królewskiego inspektor wałowego Grohnfelda. Jego forma, z toskańskimi kolumnami czy belkowaniem szczytu, nie przypominała zagrody chłopskiej. Jak podkreślał Schmid, zastosowane tam motywy były licznie kopiowane w kolejnych latach przez innych gospodarzy ${ }^{94}$.

$\mathrm{Na}$ początku lat 30. XX w. przeprowadzono również prace przy bramach prowadzących do zagród w Gronowie Elbląskim Grunau i Jasionnej Eschenhorst (il. 5) ${ }^{95}$. W 1934 r. odremontowano jeszcze jedną bramę w Pastwie Gross Weide z 1776 r., dla której pomoc przyznało Bund Deutscher Osten ${ }^{96}$.

$\mathrm{Na}$ ochronę domu z 1800 r. w Pruchniku Dörbeck w połowie lat 30. XX w. wpływ miało jego znaczenie krajobrazowe w przestrzeni wsi, a także historia rodziny Stegmann, znanej tu od XVII w. ${ }^{97}$ Zdarzało się, że bardzo duże domy zmieniały swoja funkcję. Tak stało się m.in. w Bagarcie Baumgarth, gdzie w remontowanym domu zamieszkały trzy rodziny. Dodatkowo budynek ten był jedną z dwóch zachowanych zagród odbudowanych

92 Ibidem; R. Paszkowski, katalog nr 253.

93 Die Denkmalpflege in der Provinz. Westpreußen in den Jabren 1920 bis 1931 ..., s. 24; R. Paszkowski, katalog nr 178.

94 Die Denkmalpflege in der Provinz. Westpreußen in den Jabren 1920 bis 1931..., s. 25; R. Paszkowski, katalog nr 119, 175.

95 W Jasionnej czytelne było jeszcze marmoryzowanie belkowania i romboidalne malowidła listew bramy, głównie w czerwonym kolorze. Zob. Die Denkmalpflege in der Provinz Westpreußen in den Jahren 1920 bis 1931..., s. 25; R. Paszkowski, katalog nr 95, 105.

${ }_{96}$ Die Denkmalpflege in der Provinz. Westpreußen in den Jahren 1932 bis 1935. 18. Bericht an den Herrn Oberpräsidenten der Provinz. Ostpreußen erstattet von Bernhard Schmid Provinzialkonservator für den Regierungsbezirk Westpreussen, Königsberg 1936, s. 16; R. Paszkowski, katalog nr 183.

${ }_{97}$ Die Denkmalpflege in der Provinz Westpreußen in den Jahren 1932 bis 1935. 18. Bericht an den Herrn Oberpräsidenten der Provinz. Ostpreußen erstattet von Bernhard Schmid Provinzialkonservator für den Regierungsbezirk. Westpreussen, Königsberg 1936, s. 15; R. Paszkowski, katalog nr 194. 
po pożarze wsi w 1794 r., mających jeszcze tradycyjny układ i konstrukcję. W tym momencie jedyną szansa zachowania podcienia mogła być pomoc publiczna, dzięki której przeprowadzono remont w 1935 r. pod kierunkiem miejskiego urzędu budowlanego w Sztumie ${ }^{98}$.

Dodatkowo pomoc przyznano: gospodarzowi Giesebrecht, właścicielowi zagrody z 1777 r. w Różanach Alt Rosengart9 ${ }^{9}$, dwóm zagrodom z Markus Markushof - Hermanna Wiehlera z 1784 r. ${ }^{100}$ oraz Krolla z 1793 r. ${ }^{101}$, domowi Friesena z końca XVIII w. w Szaleńcu Törichthof ${ }^{102}$, Wintera z 1730 r. w Żurawcu Schwansdorf ${ }^{103}$, Paula Kuhna I w Pruchniku Dörbeck ${ }^{104}$, Elizabeth Janzen z 1822 r. w Kępniewie Kampenau ${ }^{105}$, Fritza Wiehlera z 1775 r. w Markusach Markushof ${ }^{106}$ oraz Roberta Harmsa z 1749 r. w Rozgartach Preussische Rosengart ${ }^{07}$. Prace te polegały głównie na remoncie podcienia, wymianie pokrycia dachowego, przebudowie łatwopalnych kominów oraz budowie ścian przeciwogniowych. W 1937 r. przeprowadzono

98 Die Denkmalpflege in der Provinz. Westpreußen in den Jahren 1932..., s. 16; R. Paszkowski, katalog nr 2.

99 Die Denkmalpflege in der Provinz. Westpreußen in den Jahren 1932..., s. 16; R. Paszkowski, katalog nr 209.

100 Die Denkmalpflege in der Provinz. Westpreußen in den Jahren 1932..., s. 16; R. Paszkowski, katalog nr 155.

101 Die Denkmalpflege in der Provinz. Westpreußen in den Jahren 1932..., s. 18; R. Paszkowski, katalog nr 156.

102 Die Denkmalpflege in der Provinz. Westpreußen in den Jahren 1932..., s. 16; R. Paszkowski, katalog $\mathrm{nr} 227$.

103 Die Denkmalpflege in der Provinz. Westpreußen in den Jahren 1932..., s. 17; R. Paszkowski, katalog nr 256.

104 Die Denkmalpflege in Westpreußen in den Jabren 1936 bis 1940. Von Dr. Bernhard Schmid, Provinzialkonservator für den Regierungsbęirk Westpreussen, Königsberg 1940, s. 8; R. Paszkowski, katalog nr 126.

105 Wieńcowy dom z 1822 r. miał wspaniały podcień z 12 kolumnami o formach klasycystycznych. Plan i bryła były charakterystyczne dla XVIII w. Pracami w wysokości 1600 marek kierowal sam Schmid. Die Denkmalpflege in Westpreußen in den Jahren 1936..., s. 9; R. Paszkowski, katalog nr 115.

106 Właściciel otrzymał 900 marek pomocy od państwa, 800 od prowincji i 100 od powiatu. Prace przeprowadzono w 1938 r. Zob. Die Denkmalpflege in Westpreußen in den Jahren 1936..., s. 10; R. Paszkowski, katalog nr 157.

107 Prace przyznano w 1936 r. Państwo przyznało pomoc w wysokości 500 marek, prowincja - 300 i powiat 70 . Zob. ibidem. 
również prace przy podcieniu obory w zagrodzie Paula Kuhna w Krzewsku Hohenwalde ${ }^{108}$.

W zagrodzie Hermanna Froese z końca XVIII w. w Kławkach Klackendorf pomoc przyznano celem przywrócenia pierwotnej formy podcienia (il. 6). Drewniane kolumny zostały w poprzednich latach zastapione murowanymi filarami, a szczyt został oszalowany. Dzięki zachowanym w belce podcienia otworom po kołkowaniu oryginalnych elementów, bez problemu można było odtworzyć podpory. Szczyt otrzymał szkielet z wypełnieniami dekoracyjnymi, zachowując tradycyjną ciesiołkę. Przywrócenie oryginalnej formy domów było według Schmida również ważne ze względów krajobrazowych. Zagroda usytuowana była przy głównej drodze prowadzącej przez wieś ${ }^{109}$. Dodatkowo w 1939 r. podczas budowy nowej obory w tej zagrodzie pozostawiono podcień starej, pochodzącej z końca XVIII w. ${ }^{110}$

W latach 30. przeprowadzano również prace przy budynkach, które wcześniej otrzymały dofinansowanie. Tak było w przypadku Stalewa. Regres gospodarczy w latach 20. XX w. nie pozwalał właścicielowi na bieżące remonty domu, stąd ponownie otrzymał on finansową pomoc państwa. Argumentem była również popularność zagrody, często odwiedzanej jako wspaniały zabytek sztuki chłopskiej oraz reprodukowanej i opisywanej w publikacjach o regionie ${ }^{111}$.

Tak samo postapiono z domem Alfreda Wiehlera z 1750 r. w Kleciu (il. 7). W 1929 r. przeprowadzono remont podcienia. Już wcześniej, gdy urządzono w nim mieszkania, robotnicze budynek przestał pełnić rolę samodzielnej zagrody. Dopiero w latach 30. ponownie stał się samo-

108 Państwo i prowincja przyznały na ten cel po 400, powiat zaś 100 marek. Zob. Die Denkmalpflege in Westpreußen in den Jabren 1936..., s. 9; R. Paszkowski, katalog nr 126.

109 Die Denkmalpflege in der Provinz. Westpreußen in den Jahren 1932 bis 1935. 18. Bericht..., s. 17; R. Paszkowski, katalog nr 120. Zob. również: F. Braun, Im Lande der Weissmäntel. Land und Leute im deutschen Weichselga, 1913, s. 48b; B. Schmid, Die Bau-und Kunstdenkmäler des Kreises Marienburg..., s. 304; W. Bayreuther, Westpreussen in Wort und Bild, Königsberg 1927, s. 60, Abb. 45; K. H. Clasen, Marienburg und Marienwerder, Berlin 1931, Abb.46 [za: Die Denkmalpflege in der Provinz. Westpreußen in den Jahren 1932 bis 1935. 18. Bericht..., s. 17].

110 Die Denkmalpflege in Westpreußen in den Jabren 1936 bis 1940..., s. 9.

111 Por. F. Braun, op. cit., s. 48b; B. Schmid, Die Bau-und Kunstdenkmäler des Kreises Marienburg..., s. 304; W. Bayreuther, Westpreussen in Wort und Bild, Königsberg 1927, s. 60, Abb. 45; K. H. Clasen, op. cit. 
dzielnym gospodarstwem. W 1935 r. przeprowadzono prace remontowe, podczas których z powodu złego stanu zachowania na nowo wykonano wiele elementów.

Dotację przyznano również gospodarzowi z Wilkowa. W 1938 r. z pomoca państwa wyremontowano dom, przy którym prowadzono prace już w 1911 r. Państwo i prowincja przyznały na ten cel po 400 marek $^{112}$.

Względy krajobrazowe przesądziły również o ingerencji konserwatora w wygląd nowych domów. W Kamienniku Wielkim Stoboy Walther Hormann otrzymał dofinansowanie do budowy celem postawienia podcienia. Analogicznie postapiono przy budowie domu Emilii Schulz w Pruchniku Dörbeck ${ }^{113}$. Jedną z ostatnich prac wykonano przy zagrodzie Wegnera z 1779 r. w Mątowskich Pastwiskach Montanerweide. Budynek ten był bardzo zaniedbany, a właściciel, który odziedziczył go po pierwszej wojnie światowej, nie był w stanie ponieść kosztów remontu. Dzięki wysokiej wartości historyczno-kulturalnej ministerstwo przyznało 2900 marek, nadprezydent Prus Wschodnich 2700, powiat kwidzyński 200 RM, co dało łączną sumę 5800 marek pomocy pozostających do dyspozycji właściciela. Prace rozpoczęły się w czerwcu 1938 i ciagnęły się do 1940 r. ${ }^{114}$

W zakończeniu ostatniego sprawozdania w 1940 r. Schmid wyraził przekonanie, że celem ochrony konserwatorskiej powinny stać się również dawne zwyczaje chłopskie. W powiecie malborskim trzem wsiom starosta podczas dożynek wręczył laski sołtysie, które wykonane zostały w warsztatach zarządu odbudowy zamku malborskiego. Wskazywał także na problemy zachowania tradycyjnego układu wsi z podcieniowymi domami, placem wiejskim i zadrzewieniem, podając jako przykład Oleśno ${ }^{115}$. W pojedynczych przypadkach ochronie podlegały również pomniki przyrody o wartości historycznej ${ }^{116}$.

\footnotetext{
112 Die Denkmalpflege in Westpreußen in den Jahren 1936 bis 1940..., s. 10.

113 Ibidem; R. Paszkowski, katalog nr 111.

114 Die Denkmalpflege in Westpreußen in den Jahren 1936 bis 1940..., s. 10; R. Paszkowski, katalog nr 158.

115 Die Denkmalpflege in Westpreußen in den Jahren 1936 bis 1940..., s. 11.

116 Die Denkmalpflege in der Provinz. Westpreußen im Jahre 1907. Bericht an die Provinzialkommission zur Verwaltung der westpreußischen Provinzialmuseen zu Danzig erstattet vom Provinzialkonservator, Danzig 1908, s. 24; R. Paszkowski, op. cit., katalog nr 138.
} 
Reasumując, należy stwierdzić, że początki działalności konserwatora prowincji należy łączyć z aktywnością Gulgowskich we Wdzydzach Kiszewskich, gdzie utworzono pierwsze na tym terenie muzeum na wolnym powietrzu. W dalszej kolejności wszelkie prace koncentrowały się na zabudowie Żuław. Polegały głównie na dofinansowaniu bieżących remontów domów. Odzwierciedlało to już wagę, jaka przywiązywano do tej specyficznej zabudowy w krajobrazie Żuław. Według funkcjonującego prawa o przyznanie środków zwracać musieli się sami właściciele. Prace przeprowadzano głównie przy podcieniach, zabezpieczając je i przywracając ich pierwotną formę. W dalszej kolejności finansowano zabezpieczenie przeciwogniowe, tj. wymianę pokrycia dachowego, przemurowanie łatwopalnych kominów sztagowych czy wprowadzanie ścian przeciwogniowych. Co niezmierne ważne, wysokość dofinansowania dochodziła nawet do 80\% kosztów. Prace w wielu wypadkach prowadził mistrz ciesielski Karl Goldmann. Remonty, choć prowadzone historycznymi technikami budowalnymi (często po analizie zachowanych starych śladów), miały jednak głównie na celu zachowanie lub przywrócenie oryginalnej formy domów. Prace na szerszą skalę zaczęto podejmować od końca lat 20 . XX w. Związane było to ze zmianą granic prowincji, a więc również znacznym uszczupleniem zasobu zabytkowego. Z drugiej strony to właśnie w zachowaniu zabudowy chłopskiej dostrzeżono ważną oręż w utrzymaniu niemieckości na Wschodnie. Najcenniejsze domy otrzymywały pomoc nawet kilkakrotnie. Pieniądze na ten cel płynęły z ministerstwa, prowincji, powiatu i stowarzyszeń. Zainteresowanie zaś zwyczajami ludowymi i ingerencja konserwatorska w ich zachowanie wpisuje się bezpośrednio w tak modny obecnie nurt ochrony dziedzictwa niematerialnego.

\section{Działania konserwatorskie podejmowane przy młynach}

Obok charakterystyki działań przy zagrodach osobną uwagę należy poświęcić także młynom. W pierwszej kolejności były one związane z pracami konserwatorskimi na zamku krzyżackim w Malborku. W latach 1901-1902 w fosie międzymurza zachodniego zbudowano duży, murowany 
młyn ${ }^{117}$. Do 915 r. celem jego wyposażenia Steinbrecht prowadził systematyczne zakupy oryginalnych urządzeń z terenu całych Żuław ${ }^{118}$. W 1913 r. w ramach tych działań Zarząd Odbudowy Zamku zakupił fragmenty wiatraka odwadniającego z Krzewska Hohenwalde, zbudowanego w 1831 r. Jego fragmenty (wały z kołami) zostały wyeksponowane w fosie zamkowej i krużgankach. W 1924 r. Werner Dobisch wykonal także jego rysunkową rekonstrukcję (il. 8) ${ }^{119}$.

W latach 30. XX w. problem zachowania wiatraków (których było jeszcze w prowincji 62) został dostrzeżony przez konserwatora prowincji. Z powodu większej wydajności młynów przemysłowych przestawały one stopniowo spełniać swoją funkcję. Dostrzegano natomiast ich dużą wartość krajobrazową i historyczną - na terenie Żuław znane były bowiem już od średniowiecza. Schmid podkreślał również ich walor jako dzieł sztuki i kultury. Dokonał także ich podziału na: koźlaki, paltraki, dwa rodzaje holendrów oraz wiatraki wieżowe. Osobna kategorią były wiatraki odwadniające (il. 9c), które w tym czasie nie były już użytkowane. Starsze miały konstrukcję koźlaków z kołem zewnętrznym. W XIX w. pojawiły się wiatraki z obrotowa głowica, gdzie koło czerpakowe znajdowało się w korpusie młyna. Przykładem takim był wiatrak w Krzewsku, którego fragmenty złożono na zamku malborskim.

Najstarsze wiatraki pochodzące z XVIII w. znajdowały się w: Różanie Alt Rosengart z 1730 r. (il. 9d), Markusach Markushof z 1782 r., Ostaszewie Schöneberg z 1686 r. Ostatni zaś wiatrak na tym terenie zbudowano w 1882 r. $^{120}$

117 W źródłach zawarte były wzmianki z XV w. o pracach ciesielskich przy młynie. Podczas badań archeologicznych nie odnaleziono jednak żadnych jego reliktów. Młyn Steinbrechta uznać należy zatem za jego kreację artystyczną. Zob. W. Długokęcki, J. Kuczyński, B. Pospieszna, op. cit., s. 81.

118 Do najważniejszych zakupów należało pełne wyposażenie z 1826 r. młyna kaszowego z Kościeleczek. Zob. ibidem, s. 82-83 oraz http://www.mlyn.zamek.malbork.pl/ [09.02.2014].

119 APM, Zarząd Odbudowy Zamku, sygn. 980; W. Długokęcki, J. Kuczyński, B. Pospieszna, op. cit., s. 83.

120 Die Denkmalpflege in der Provinz. Westpreußen in den Jabren 1920 bis 1931. 17 Bericht..., s. 27. 
Konserwator wyraźnie podkreślił, że jedyną możliwą formą ich ochrony w tym wypadku był zakup najwartościowszych budowli ${ }^{121}$. Pierwsze inicjatywy w tym zakresie podjęto w Europie w 1923 r. przez stowarzyszenie młynów holenderskich Verein "de bolandsche Molen” z Niderlandów. W 1927 r. senat Wolnego Miasta Gdańska objął ochroną trzy najważniejsze młyny odwadniające w Orłowie Orloff, Orłowskim Polu Orloffenfelde i Ostaszewie Schöneberg ${ }^{122}$.

W 1929 r. Schmid opracował raport na temat młynów w powiecie malborskim. We wstępie historycznym, na podstawie źródeł, opisał młyny działające już w średniowieczu. W dalszej części przedstawił obecny stan zachowania oraz główne zagrożenia wynikające $z$ braku funkcji użytkowych. Jednocześnie wymienił najważniejsze egzemplarze, które powinny zostać objęte ochroną ${ }^{123}$.

W latach 1930-1931 na wniosek konserwatora powiat malborki zakupił i wyremontował dwa młyny: odwadniajacy w Dzierzgonce Sorgenort i koźlaka w Markusach ${ }^{124}$. W niektórych wypadkach, pomimo prośby właścicieli, konserwator nie zgadzał się na dofinansowanie. Tak był w przypadku wiatraka Artura Rohde w Czerwonce Rothebud ${ }^{125}$. Po wizji lokalnej oddalono wniosek ze względu na małą wartość młyna, który był mocno przebudowany $^{126}$.

W 1932 r. powiat sztumski wykupił wiatrak w Białej Górze Weißenberg. Obok niego zbudowano małe schronisko młodzieżowe, nadając mu nowa

\footnotetext{
121 Ibidem, s. 25-26.

122 Ibidem, s. 28.

123 APM, Wydział Powiatowy w Malborku, sygn. 492 (Instandsetzung alter Müblen des Kreises im Allgemeinen 1929-1933), k. 36-38.
}

124 Ibidem, k. 28. Młyn w Markusach, którego właścicielem był Ernest Penner, w korespondencji ujmowano również jako z Wengeln (Węgle-Żukowo) oraz Augustwalde (Wiśniewo). Prośbę o remont właściciel złożył już w 1929 r. Zob. ibidem, k. 1. Koszt całkowity prac przy każdym wiatraku obliczono na 3400 marek. W tym dla wiatraka w Dzierzgonce - zakup 700, pomiar i opis 100 oraz naprawa 2600 marek. Dla wiatraka w Markusach - zakup 1200, pomiar i opis 200, naprawa 2000 marek. W dalszej kolejności do zakupu i prac przeznaczono wiatrak w Różanie. Zob. ibidem, k. 10-11.

125 Właściciel złożył pismo z prośbą o dofinansowanie 17 lipca 1930 r. Zob. ibidem, k. 28. 126 Wizyta miała miejsce 28 sierpnia $1930 \mathrm{r}$. Młyn poruszany był silnikiem. W niewielkim stopniu zachowany był pierwotny układ napędowy ze skrzydłami. Koszty odbudowy młyna byłyby zbyt wysokie. Zob. ibidem, k. 30, 32 . 
funkcję ${ }^{127}$. Dzięki pomocy państwowej wyremontowano również koźlaka w Gardei Garnsee-Dorf, w Kwidzynie-Podzamczu Unterberg własności Liedtke z ok. 1840 r. oraz w Kępniewie Kampenau z 1840 r. własności Elizabeth Janzen (il. 9a,b) ${ }^{128}$, holendra Panzlaua z połowy XIX w. w Gałdowie Goldau ${ }^{129}$. Prace wykonano również w Różanie przy najstarszym koźlaku na Żuławach z 1730 r. ${ }^{130}$ Górny gzyms miał dekoracje rzeźbiarskie o formach barokowych. Schmid podkreślal, że jest to szczególnie cenny zabytek kultury. Pieniądze na remont w wysokości 1750 marek przyznał minister, prowincja i powiat malborki ${ }^{131}$. Prace przy większości młynów prowadził znany już Karl Goldmann. O problemach z pozyskaniem środków na ochronę wiatraków najlepiej świadczą sześcioletnie starania o dofinansowanie prac przy holendrze w Wielkim Wikrowie Gross Wickerau. Młyn ten był połączony z domem młynarza i gospoda, stanowiąc szczególna grupę zabudowy. Dodatkowo z pagórka wiatracznego roztaczał się piękny widok na Elblag. Prace przeprowadzono w 1935 r. oraz dodatkowo trzy lata później, gdy założono instalację odgromową ${ }^{132}$.

Tak jak w przypadku zagród najbardziej preferowanym rozwiązaniem były dofinansowania remontów, tak w przypadku wiatraków głównie chodziło o ich zakup i udostępnienie społeczeństwu. Oczywiście w uzasadnionych przypadkach pomagano także prywatnym właścicielom. W wiatrakach dostrzegano ich znaczenie dla krajobrazu nizin oraz wartości zabytku techniki czy ciesiołki. Schmid miał pełną świadomość, że już na początku XX w. ten ważny zasób, poprzez zanik funkcji, skazany jest na zapomnie-

127 Die Denkmalpflege in der Provinz. Westpreußen in den Jahren 1932 bis 1935. 18. Bericht..., s. 18; R. Paszkowski, katalog nr 4.

${ }^{128}$ Prace przy nim wykonano w 1933 r. oraz ponownie w 1937, kiedy to wiatr złamał dwa skrzydła. Zob. ibidem; Die Denkmalpflege in Westpreußen in den Jabren 1936 bis 1940..., s. 9; R. Paszkowski, katalog nr 116. Zob. również: APM, Wydział Powiatowy w Malborku, sygn. 492, k. 77-100.

${ }_{129}$ Die Denkmalpflege in Westpreußen in den Jahren 1936 bis 1940..., s. 10; R. Paszkowski, katalog nr 52.

130 Kosztorys zatwierdzono 13 maja 1933 r. Zob. APM, Wydział Powiatowy w Malborku, sygn. 492, k. 68-71.

131 Die Denkmalpflege in der Provinz. Westpreußen in den Jahren 1932 bis 1935. 18. Bericht..., s. 18; R. Paszkowski, katalog nr 250.

132 Ibidem; Die Denkmalpflege in Westpreußen in den Jahren 1936 bis 1940..., s. 10. 
nie. Jedynie w działaniach konserwatora dostrzegał możliwość zachowania najcenniejszych przykładów ${ }^{133}$.

\section{Podsumowanie}

Przedstawiony powyżej rozwój zainteresowania zabytkoznawczego oraz działania konserwatorskie podejmowane przy architekturze wiejskiej w granicach Prus Zachodnich skłaniają do kilku wniosków natury ogólnej.

Po pierwsze, od samego początku uwagę skupiano na zabudowie Kaszub i Żuław. Pionierem naukowej analizy tej zabudowy, popartej kwerendą źródeł, badań terenowych, a także samej substancji zabytkowej, był Bernhard Schmid, który metodę tę wyniósł zapewne z pracy w Zarządzie Odbudowy Zamku w Malborku. Przez cały czas w formie tej zabudowy udowadniał wpływu kolonizacji niemieckiej w okresie średniowiecza. Była ona również istotnym instrumentem wykorzystywanym propagandowo przez państwo, co niewateliwie sprzyjało przy ubieganiu się o środki finansowe, zwłaszcza że były one zdecydowanie mniejsze niż w przypadku prac przy np. kościołach.

W przypadku działań konserwatorskich Bernhard Schmid zawsze starał się o zachowanie zabudowy w jej pierwotnej lokalizacji. Pomoc przyznawano głównie domom podcieniowym, tym najstarszym z połowy XVIII w., młodszym, a nawet nowym budynkom, tak aby współczesna architektura dopasowywała się do historycznego krajobrazu kulturowego Żuław. W kręgu zainteresowań pozostawały też budynki gospodarcze, mała architektura, pomniki przyrody i oczywiście wiatraki.

W całościowym spojrzeniu należy stwierdzić, że zabudowa wiejska była jedną z największych grup obok kamienic mieszczańskich, przy których podejmowano prace $\mathrm{w}$ XX w. ${ }^{134} \mathrm{Z}$ drugiej strony widać tu swoista gradację wartości. Inaczej bowiem podchodzono np. do architektury lub rucho-

133 Wydaje się również, że zachowaniu wiatraków sprzyjała również ich przydatność wojskowa. Służyły one jako punkty triangulacyjne i zarazem obserwacyjne. Świadczy o tym zaznaczanie ich na mapach sztabowych.

134 Zob. R. Paszkowski, katalog prac. 
mych dzieł średniowiecznych, jak np. ołtarze, rzeźby czy malarstwo. Zakres ingerencji był w nich bardzo zachowawczy. Uzupełnienia wg ówczesnych standardów wykonywano w minimalnym stopniu, a rekonstrukcje przeprowadzano jedynie w uzasadnionych naukowo wypadkach ${ }^{135}$. W zabudowie wiejskiej dostrzegano głównie formę tworząca całościowo zwarty krajobraz kulturowy. W wielu zagrodach działania polegały głównie na większym zabezpieczeniu przeciwogniowym ${ }^{136}$.

Jak zatem, w kontekście prowadzonej polityki konserwatorskiej, postępowano na sąsiednich terenach? W 1932 r. do starosty malborskiego, którego działania nad zachowaniem młynów były już szerzej znane, zwróciło się Stowarzyszenie Cechu Młynarzy Wschodniopruskich Ostpreussischer Müllerinnungs-Verband z prośbą o informacje na temat zakupionych młynów. Sami bowiem chcieli pozyskać wiatrak w powiecie gąbińskim celem jego ochrony ${ }^{137}$. Działania konserwatora w nowo utworzonym województwie pomorskim właściwie nie były podejmowane ${ }^{138}$. W Wolnym Mieście Gdańsku bardzo szybko ochroną objęto wiatraki ${ }^{139}$. Prace prowadzono też przy do-

135 Zróżnicowanie zasad postępowania konserwatorskiego w zależności od stylów i epoki zabytku postulował już pod koniec XIX w. Camillo Boito. Z jego perspektywy najbardziej zachowawczy charakter powinny mieć prac przy zabytkach starożytnych. Zob. J. Krawczyk, Historia i teraśniejszość teorii konserwacji, [w:] Problemy konserwacij $i$ badań zabytkón architektury, red. A. Kociałkowska, Studzienka 2007, s. 25.

${ }^{136} \mathrm{~W}$ pracach tych nie niszczono jednak oryginalnej substancji. Potwierdzaja to np. badania architektoniczne zagrody w Kaniczkach. Celem wymiany pokrycia dachowego ze strzechy na dachówkę nie zmieniono oryginalnej więźby dachowej, ale wprowadzono niezależną konstrukcję płatwiową. M. Prarat, Rozwój domów podcieniowych nad Dolnq Wisła (XVIII-XIX w.) oraz ich problematyka konserwatorska w swietle badań historyczno-architektonicznych, [w:] Badania architektoniczne. Historia i perspektymy rožoju, Torun 2014 (w druku).

137 APM, Wydział Powiatowy w Malborku, sygn. 492, k. 65. W odpowiedzi powiat podał, że jest właścicielem trzech wiatraków, którym groziło rozebranie. Zwrócił także uwagę na cenę działki, na której stał młyn, jego strefy ochronnej, a także dostępu zwiedzających. Koszty prac przy młynach oszacowal pomiędzy 1000-2500 marek. Zob. ibidem, k. 66.

138 Jedynie w 1931 r. właściciel domu podcieniowego w Golubiu otrzymał zgodę na rozbiórkę budynku ze względu za zły stan zachowania. Konserwator zastrzegł jedynie, że aby tego dokonać, musi wykonać model w skali 1:50. Makieta ta znajduje się obecnie w zbiorach Działu Architektury i Parków Etnograficznych Muzeum Etnograficznego w Toruniu. Zob. K. Zimna-Kawecka, op. cit., s. 394-395.

139 Poza omówionymi wcześniej pracami, w 1933 r. wiatrak z Ostaszewa został przeniesiony na teren parku w Oliwie. Zob. J. Domino, Budownictwo..., s. 76. 
mach podcieniowych. Na przykład w Trutnowach w 1933 r. na nowo wykonano szkielet szczytów i podcienia, przywracając pierwotną ich formę ${ }^{140}$. Analogicznie zatem do działań Schmida.

W tym miejscu pojawia się pytanie o same badania architektury Żuław. Jak widać, w bardzo wielu wypadkach podlegały one znacznej ingerencji konserwatorskiej. Stąd dzisiejsza ich postać, np. w Trutnowach czy Kleciu, nie jest tylko przykładem XVIII w. formy, ale również ciesiołki z 2. ćwierci XX w. W przyszłości należałoby przeprowadzić analizę substancji remontowanych domów celem określenia metody postępowania konserwatorów. Kwerenda w archiwach berlińskich mogłaby zapewne rozszerzyć pewne wąt ki. Całość zaś podejmowanych prac i poziomu ówczesnej wiedzy o zabudowie wiejskiej na Pomorzu należałoby porównać na szerszym terenie prowincji niemieckich.

Niewątpliwie prace pruskich konserwatorów przyczyniły się do zachowania bardzo dużej liczby zagród. Niestety, wiele z nich uległo zniszczeniu podczas drugiej wojny światowej. Dobitnie pokazuje to statystyka dotycząca wiatraków. Dziś na Żuławach zachowane są tylko trzy. Nie przetrwał żaden z zabytków chronionych wcześniej na terenie powiatu malborskiego ani choć jeden wiatrak odwadniający ${ }^{141}$.

Obecnie zabudowa wsi chroniona jest dwojako. We Wdzydzach Kiszewskich, Toruniu, Kaszczorku i Wielkiej Nieszawce znajdują się parki etnograficzne. W tym ostatnim wśród budynków przeznaczonych do przeniesienia znalazła się dofinansowana przez Schmida zagroda z Kaniczek. Jej przetrwanie w miejscu powstania nie byłoby, niestety, obecnie możliwe.

Zachowana architektura, zwłaszcza na Żuławach, jest jednym z najoryginalniejszych i najcenniejszych zasobów zabudowy chłopskiej, co podkreślali już właściwie pierwsi badacze w 1. połowie XIX w. Dlatego też sprawa niezmiernie pilna jest opracowanie kompleksowego programu ochrony całego zasobu zabudowy i krajobrazu Żuław. Wychodząc od pruskich wzor-

\footnotetext{
140 E. Volmar, Wiederherstellung der Vorlaube des Hauses Ringe in Trutenau, Kreis Danziger Niederung, Mitteilungen des Westpreussischen Geschichtsvereins, Jg. 33, 1934, s. 18-19. Prowadzone badania architektoniczne $\mathrm{w}$ ramach pracy magisterskiej pod kierunkiem autora dowodzą, że konstrukcja ścianek kolankowych, podcienia i szczytów zostały wykonane na nowo w $90 \%$.
}

141 J. Stankiewicz, op. cit., s. 519-524. 
ców, działania te powinny się skupiać na powołanie parku kulturowego, w ramach którego można chronić zabudowę w miejscu. Współdziałanie władz państwowych, regionalnych, służb ochrony zabytków, stowarzyszeń, a także świadomość samych właścicieli zabytkowych domów pozwoliły na wypracowanie wzorcowego modelu ochrony zabudowy wiejskiej bez konieczności tworzenia skansenu prawie 100 lat temu. Można mieć tylko nadzieję, że uda się to i dziś, gdy przetrwały ostatnie już domy podcieniowe.

\section{Summary}

\section{Rural architecture in West Prussia as a matter of interest of Conservation and Monument Studies until the 1940s}

The aim of this paper is to familiarize the readers with the activities undertaken by Prussian conservators in the subject of rural architecture in West Prussia. The earliest studies concerning rural architecture of Pomerania dated back to the first half of the $19^{\text {th }}$ century. Conservation activities were undertaken from the early $20^{\text {th }}$ century. Several greater funds to renovate the farm buildings especially the arcaded houses in Żuławy were granted in the 1920s. Protection was also extended to the mills. Rural architecture was to symbolize the relations with German medieval settlement as well as guard the Germaness in the east. It was significant in terms of historical, landscape and monument values. 


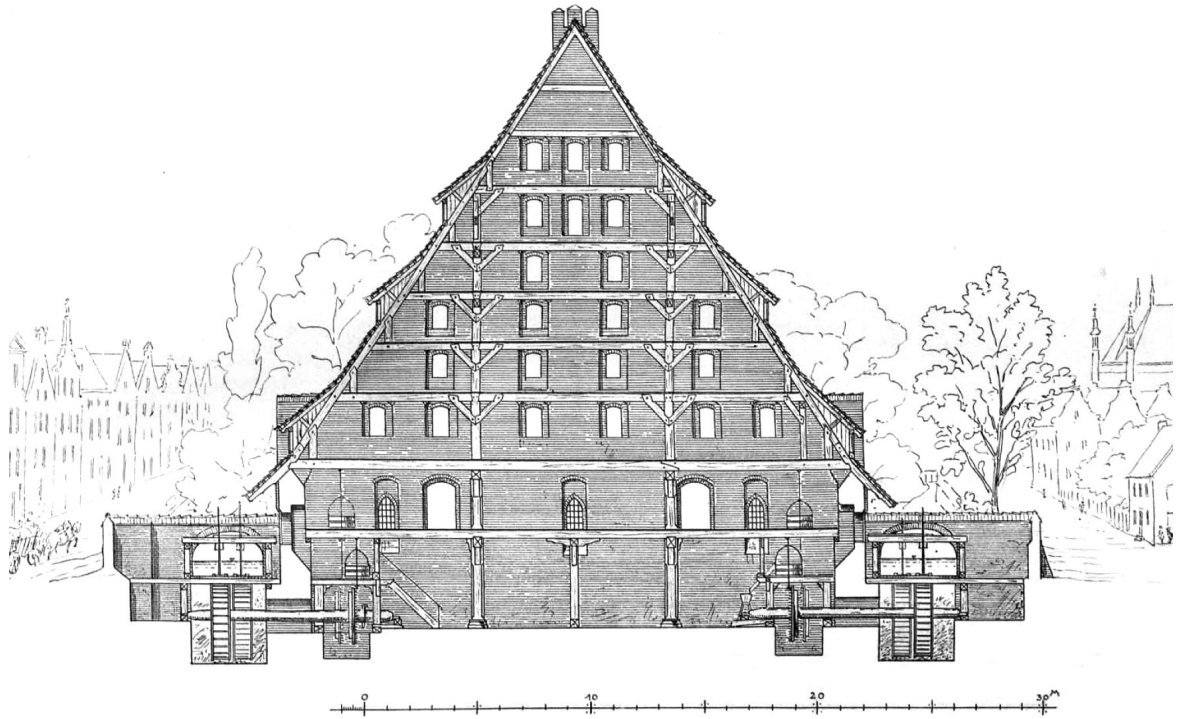

QUERSCHNITT UND BLICK GEgEN OBER-WAsser

Il. 1. Wielki Młyn w Gdańsku, przekrój poprzeczy z kołami i kamieniami młyńskimi wykonany przez C. Steinbrechta w 1880 r. (C. Steinbrecht, Die Baukunst des Deutschen Ritterordens in Preußen, Bd. 4: Die Ordensburgen der Hochmeisterzeit in Preußen, Berlin 1920, Tafel 3)

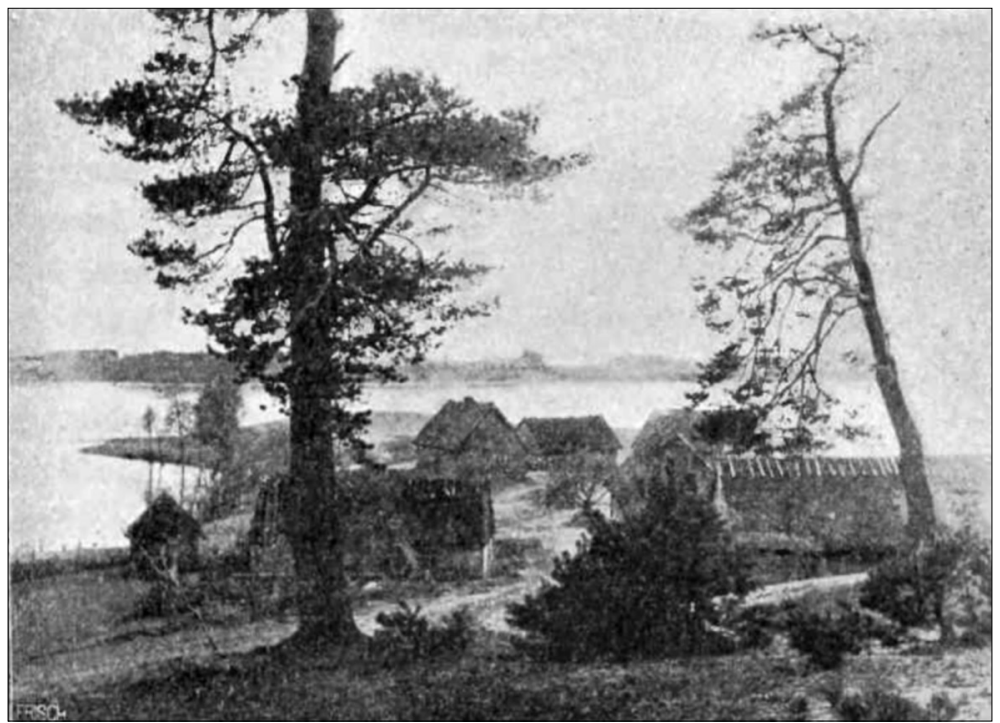

Il. 2. Wdzydze Kiszewskie, zabudowa wsi, w której Izydor Gulgowski powołał muzeum na wolnym powietrzu, 1906 r. (Die Denkmalpflege in der Provinz. Westpreußen im Jahre 1906. Bericht an die Provinzialkommission zur Verwaltung der westpreußischen Provinzialmuseen zи Danzig erstattet vom Provinzialkonservator, Danzig 1907, S. 10, Abb. 6) 


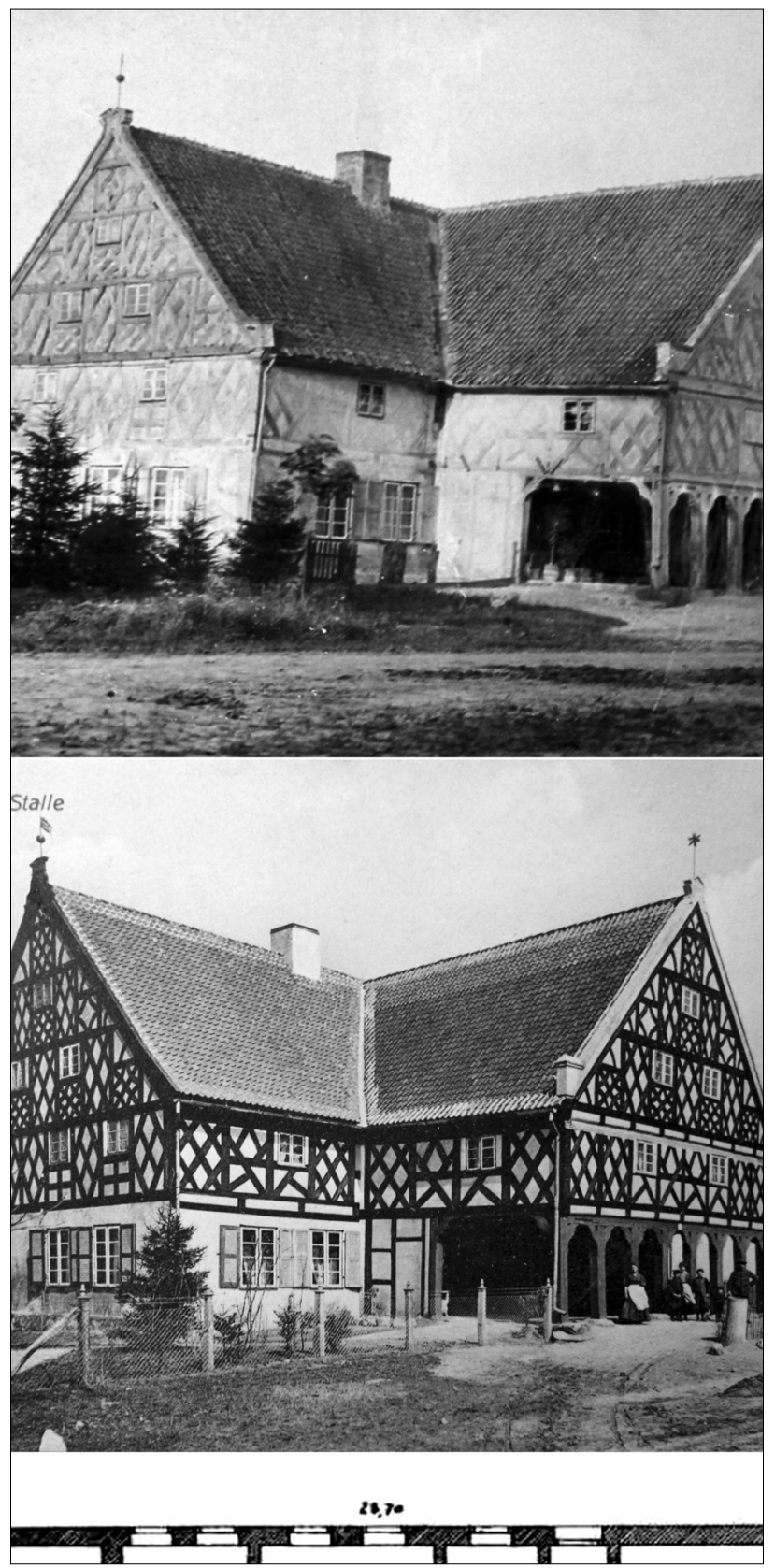

Il. 3. Stalewo, dom podcieniowy z 1751 r. a) widok na podcień przed przystapieniem do prac konserwatorskich; b) widok na zagrodę po przeprowadzonych pracach w 1908 r.; c) rzut przyziemia domu z rysunkiem pierwotnego układu przestrzenno-funkcjonalnego (il. a, b - APE, Wydział Powiatowy w Malborku, sygn. 103, k. 25; il. c - Die Denkmaltflege in der Provinz. Westpreußen im Jahre 1908. Bericht an die Provinzialkommission zur Verwaltung der westpreußischen Provinzialmuseen zu Danzig erstattet vom Provinzialkonservator, Danzig 1909, S. 13, S. 14, Abb. 10) 


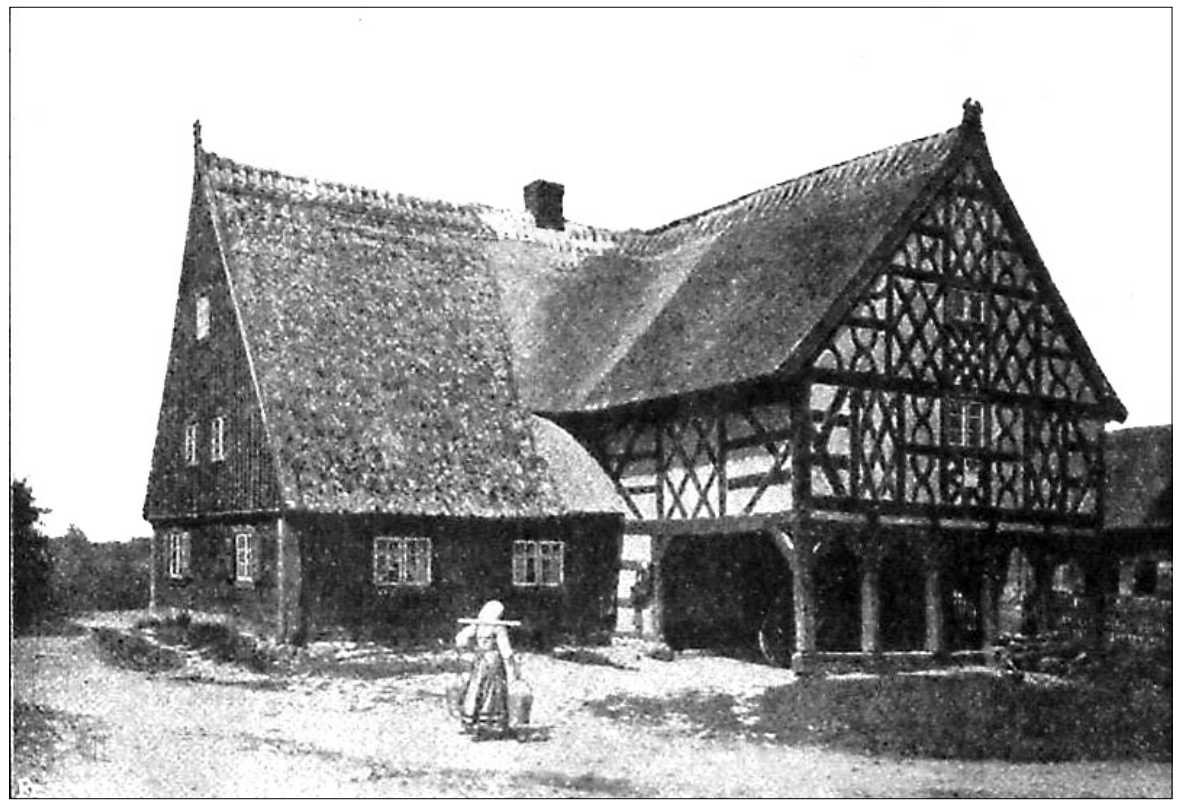

Il. 4. Wilkowo, podcieniowy dom chłopski z 1793 r. po przeprowadzonych pracach konserwatorskich (Die Denkmalpflege in der Provinz. Westpreußen im Jabre 1911. 9 Bericht an die Provinzialkommission zur Verwaltung der westpreußischen Provinzialmuseen zu Danzig erstattet von Bernh. Schmid Provinzial-Konservator, Danzig 1912, S. 21, Abb. 12)

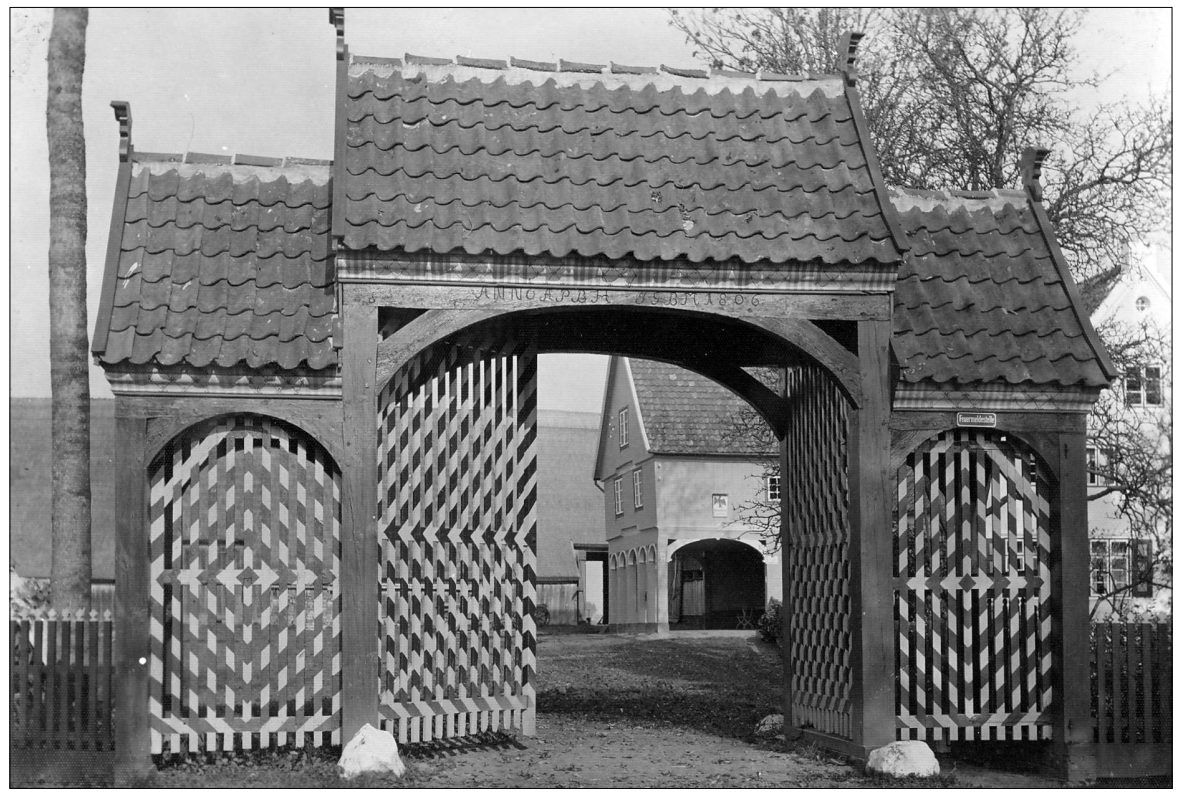

Il. 5. Jasionna, bram wjazdowa z 1806 r. do gospodarstwa po przeprowadzonych pracach konserwatorskich (Die Denkmalpflege in der Provinz. Westpreußen in den Jahren 1920 bis 1931. 17 Bericht an den Ausschluss zur Erforschung und zum Schutze der Denkmäler in der Provinz Ostpreussen erstattet von Bernhard Schmid Provinzialkonservator für den Regierungsbęirk Westpreussen, Königsberg 1932, S. 25, Abb. 7) 


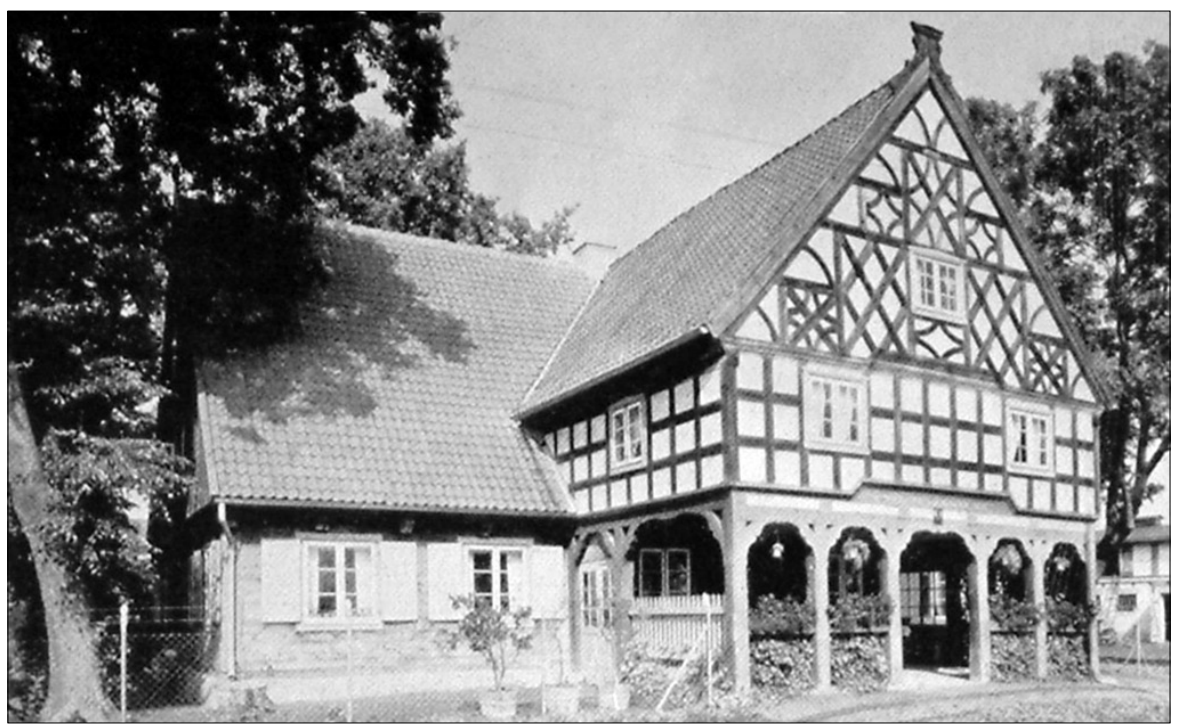

[219]

Il. 6. Kławki, dom podcieniowy z końca XVIII w. po przeprowadzonych pracach konserwatorskich (Die Denkmalpflege in Westpreußen in den Jahren 1936 bis 1940. Von Dr. Bernhard Schmid, Provinzialkonservator für den Regierungsbezirk. Westpreussen, Königsberg 1940, Abb. 8)

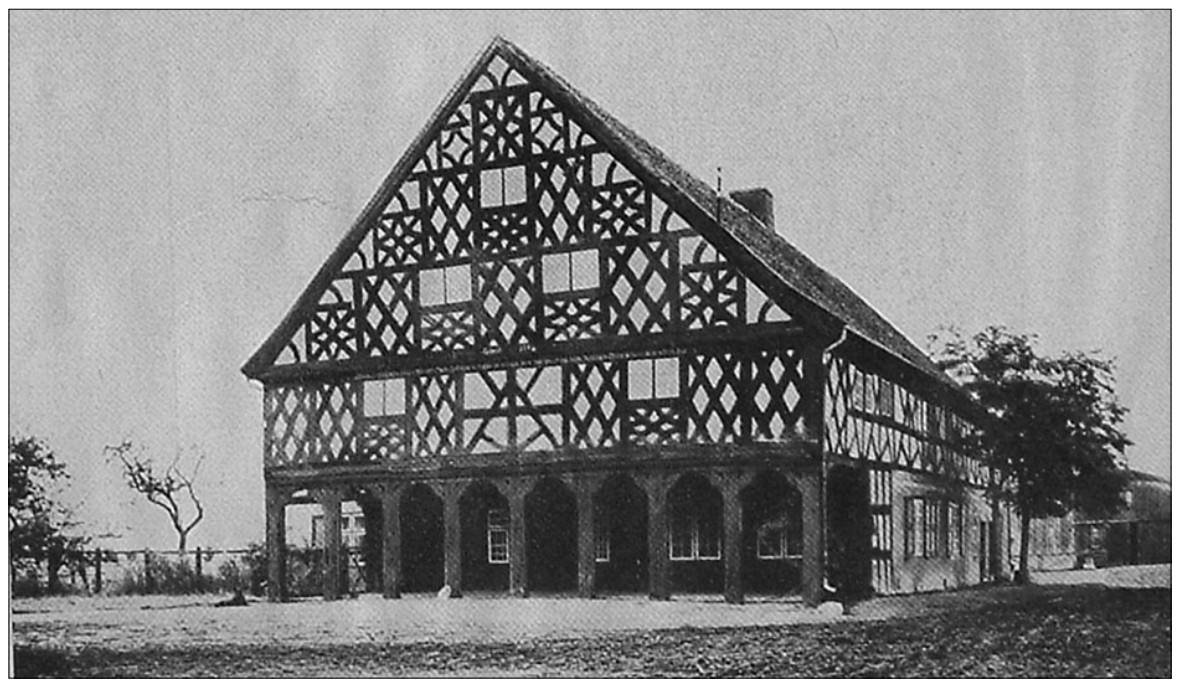

Il. 7. Klecie, dom podcieniowy z 1750 r. po przeprowadzonych pracach konserwatorskich (Die Denkmalpflege in der Provinz. Westprenßen in den Jahren 1932 bis 1935. 18. Bericht an den Herrn Oberpräsidenten der Provinz, Ostpreußen erstattet von Bernhard Schmid Provinzialkonservator für den Regierungsbezirk. Westpreussen, Königsberg 1936, S. 25, Tafel 5) 


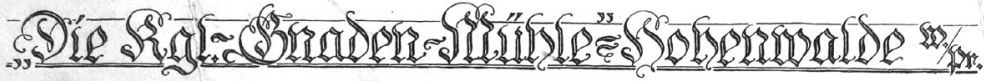

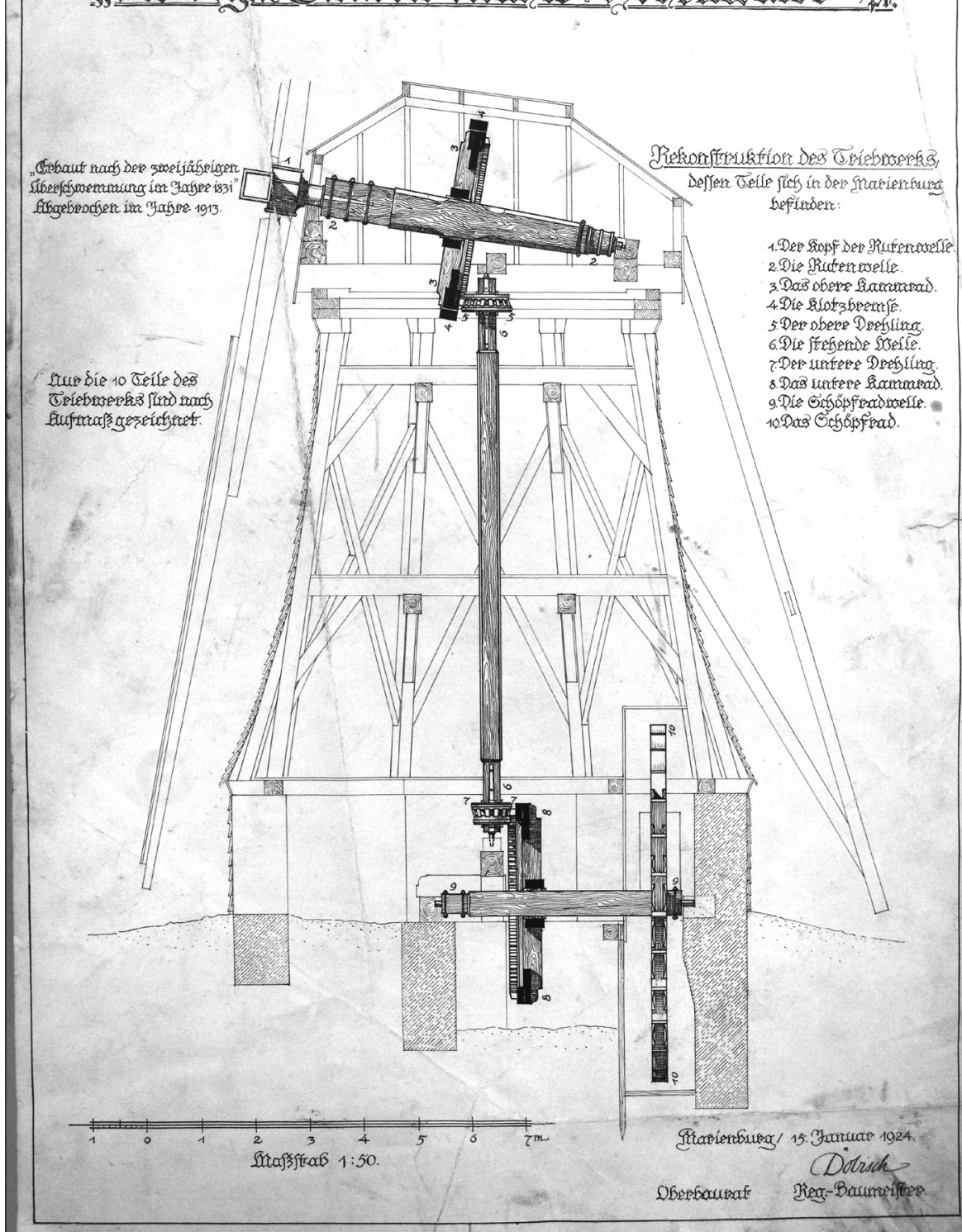

Il. 8. Krzewsk, wiatrak odwadniający. Inwentaryzacja pomiarowo-rysunkowa wykonana przez Dobischa w 1924 r. (APE, Zarząd Odbudowy Zamku, sygn. 980) 


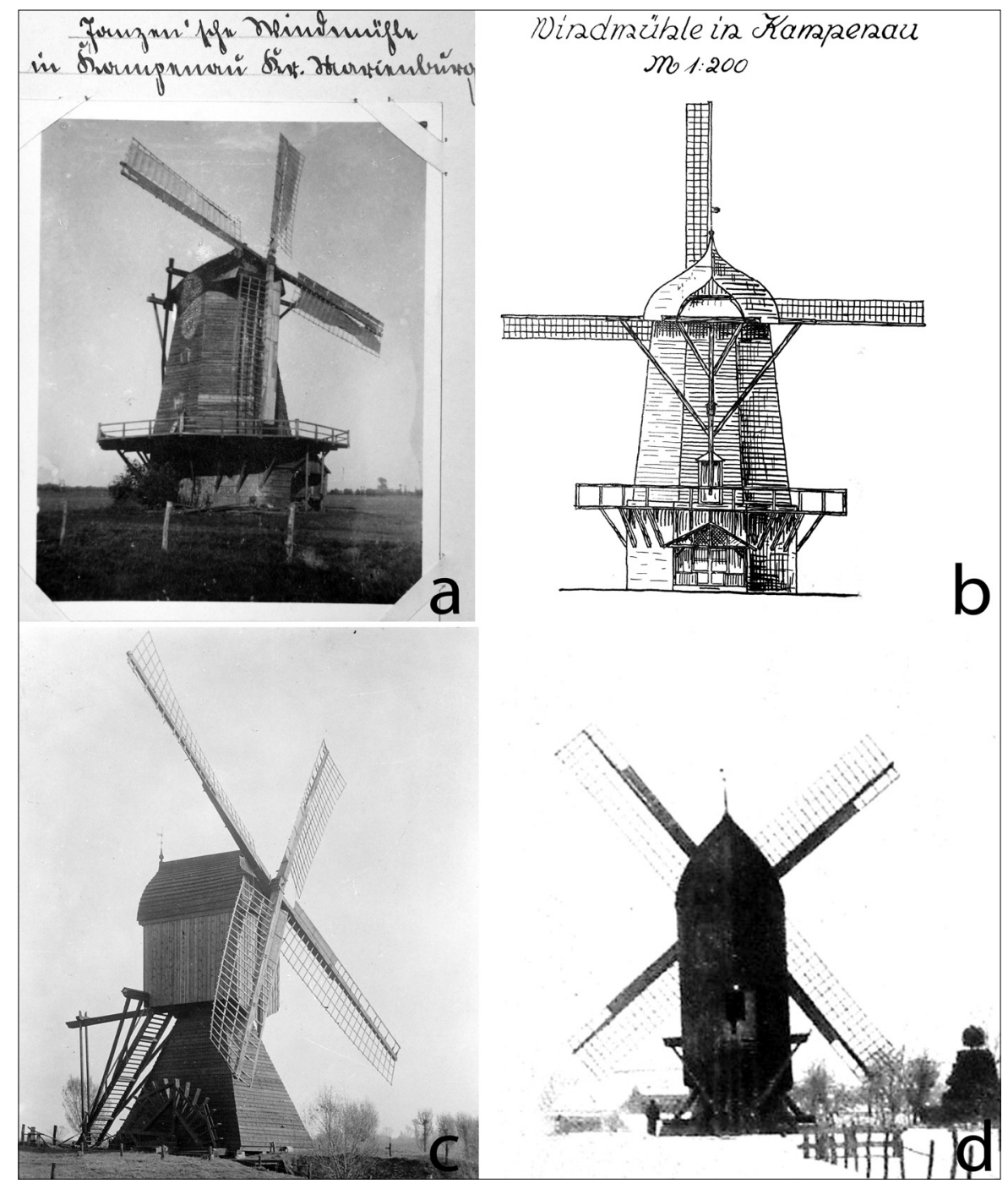

Il. 9. Wiatraki objęte ochrona przez konserwatora prowincji Prusy Zachodnie. Oznaczenia: a) wiatrak holender w Kępniewie przed podjętymi pracami konserwatorskimi; b) inwentaryzacja wiatraka w Kępniewie; c) wiatrak odwadniający; d) koźlak z Różan, 1730 r. (a, b - APM, Wydział Powiatowy w Malborku, sygn. 492, k. 88, 90, c - Die Denkmalpflege in der Provinz. Westpreußen in den Jabren 1920 bis 1931. 17 Bericht an den Ausschluss zur Erforschung und zum Schutze der Denkmäler in der Provinz Ostpreussen erstattet von Bernhard Schmid Provinzialkonservator für den Regierungsbezirk Westpreussen, Königsberg 1932, S. 25, Abb. 6; d - Die Denkmalpflege in der Provinz. Westpreußen in den Jabren 1932 bis 1935. 18. Bericht an den Herrn Oberpräsidenten der Provinz. Ostpreußen erstattet von Bernhard Schmid Provinzialkonservator für den Regierungsbezirk. Westpreussen, Königsberg 1936, S. 27, Tafel 7) 